\title{
Informing Environmental Flow Planning through Landscape Evolution Modeling in Heavily Modified Urban Rivers in China
}

\author{
Minghao $\mathrm{Wu}^{1}{ }^{1}$, Hong $\mathrm{Wu}^{2}{ }^{2} * \mathbb{C}$, Andrew $\mathrm{T}$. Warner ${ }^{3}, \mathrm{Hao} \mathrm{Li}^{1}$ and Zhicheng Liu ${ }^{1}$ \\ 1 Department of Landscape Architecture, Beijing Forestry University, Beijing 100083, China; \\ wmh_bjfu@163.com (M.W.); lh_bjfu@163.com (H.L.); zhicheng_liu@bjfu.edu.cn (Z.L.) \\ 2 Department of Landscape Architecture, The Pennsylvania State University, University Park, PA 16801, USA \\ 3 Institutes of Energy and the Environment, The Pennsylvania State University, \\ University Park, PA 16801, USA; atwarner@psu.edu \\ * Correspondence: huw24@psu.edu; Tel.: +1-814-863-5284
}

check for updates

Citation: Wu, M.; Wu, H.; Warner,

A.T.; Li, H.; Liu, Z. Informing

Environmental Flow Planning through Landscape Evolution Modeling in Heavily Modified Urban Rivers in China. Water 2021, 13, 3244. https://doi.org/10.3390/w13223244

Academic Editor: František Petrovič

Received: 27 September 2021

Accepted: 13 November 2021

Published: 16 November 2021

Publisher's Note: MDPI stays neutral with regard to jurisdictional claims in published maps and institutional affiliations.

Copyright: (c) 2021 by the authors. Licensee MDPI, Basel, Switzerland This article is an open access article distributed under the terms and conditions of the Creative Commons Attribution (CC BY) license (https:// creativecommons.org/licenses/by/ $4.0 /)$.

\begin{abstract}
Worldwide, urban rivers suffer various degrees of ecological degradation. Rehabilitating heavily modified urban rivers requires holistic approaches, including environmental flow management. We examine the case of Lower Yongding River, Beijing's mother river, which had dried up since the 1980s and is undergoing a flow replenishment experiment, receiving 342 million $\mathrm{m}^{3}$ of water during 2019-2020 for ecosystem enhancement. Considering the massive cost of replenishment, we address the urgent need to evaluate its outcomes and inform future management through an interdisciplinary modeling approach under the circumstance of severe data shortage. We simulated the study reach's landscape evolution under five flow scenarios and assessed their ecological effects using the CAESAR-Lisflood model and habitat suitability index method. Despite overall minor morphological differences across scenarios, individual reaches presented pronounced physical changes. Higher-flow scenarios shaped a distinct channel in certain reaches, but historic channel modifications by mining and farming caused minimal responses in others. Additionally, higher-flow scenarios generally created larger and more evenly distributed habitat areas but showed a low payback given the higher flow volumes needed. Targeted channel-floodplain geomorphological restoration is essential for flows to generate desired ecological outcomes. The demonstrated modeling framework offers great promise, informing future rehabilitation actions for heavily modified urban streams.
\end{abstract}

Keywords: stream ecological rehabilitation; environmental flow; landscape evolution simulation; CAESAR-Lisflood; habitat suitability; Yongding River

\section{Introduction}

Due to a long agricultural history and rapid urban development in recent decades, most rivers in China, both urban and rural, are severely degraded [1]. Nationwide, only $12 \%$ of all rivers remain potentially free-flowing or mildly disturbed [2]. Over $56 \%$ of rivers with catchments larger than $100 \mathrm{~km}^{2}$ have been lost to various disturbances [3]. Flow reduction and scarcity due to excessive abstraction, in-stream and floodplain mining, channel modifications, floodplain development, and pollution have fundamentally altered ecosystem structure and function, rendering many rivers ecologically and physically unrecognizable [4]. What is more, these challenges are likely to be exacerbated by future economic development and climate change, particularly in water-stressed northern China [5].

Urban stream rehabilitation in China was initiated relatively recently in the 1990s. Due to the urgency of addressing pollution, flood hazards, and living environment improvement, early-stage efforts have primarily focused on water quality treatment, channel stabilization, and riparian greening at the channel scale [6], with significant achievements in waterfront open space planning and design, engineering solutions, and landscape and cultural value conservation [7]. However, limited progress has been made in urban river 
ecological restoration [8] with respect to returning the aquatic ecosystems to a close approximation of their prior-to-disturbance conditions $[9,10]$. Besides the low feasibility of holistically restoring severely degraded river ecosystems in urban settings, another critical barrier lies in the general lack of fundamental understanding of urban stream ecosystem structure and function due to scarce baseline ecological and hydrological data [11]. Nonetheless, a shift in restoration paradigms has emerged since 2005, from the channelbased single-objective approach to a more holistic one that integrates cross-scale strategies to achieve multiple environmental, social, and economic benefits [12]. A flux in policy and implementation initiatives has been launched since 2011 to lay regulatory foundations for new endeavors in urban stream ecological restoration [13,14].

The subject of this study, the Lower Yongding River (YDR), also known as the mother river of Beijing, dried up for nearly four decades from the early 1980s to 2019. It marks a new initiative in China of using environmental flow replenishment to enhance heavily modified urban rivers. Environmental (or ecological) flows (EF) are defined as "the quantity, timing and quality of water flows required to sustain freshwater and estuarine ecosystems and the human livelihoods and well-being that depend on these ecosystems" [15]. Although EF management is not new in ecological restoration in China, it has primarily been applied in large river basins, such as the Yellow and Yangtze river basins [16,17]. Due to the ecological and cultural significance of YDR to Beijing, the National Development and Reform Commission, Ministry of Water Resources, and State Forestry Administration of China jointly launched a cross-provincial program in 2017, "The General Plan of Comprehensive Treatment and Ecological Restoration for the Yongding River Basin (YDRB)," outlining a multi-scalar watershed management plan with both upland and channel restoration strategies to enhance the ecological conditions of the entire basin [18]. Early efforts began in 2019 and included the transfer of 132 and 210 million $\mathrm{m}^{3}$ of water (measured at the Sanjiadian gauging station) from the Yellow River Basin to YDRB in 2019 and 2020, respectively [19].

While such large-scale flow replenishment offers exciting opportunities for improving the ecological conditions of YDRB, the experimental stage, early understanding of the environmental flow approach, significant historical channel modifications, and lack of paired ecological and hydrological baseline information bring extraordinary challenges in understanding the exact ecological ramifications of restoration efforts. However, given the massive investment and severe nationwide water scarcity (e.g., per capita freshwater resources in China are less than one-quarter of the world average) [20], it is absolutely critical to evaluate the outcomes of flow replenishment, not only to justify inter-provincial transportation of flows, water that the country could not waste, but also to inform future stream restoration efforts.

This article explores the effectiveness of various flow replenishment scenarios in reshaping the Yongding River channel through simulating landscape evolution and assessing habitat suitability based on channel physical outcomes. Since the articulation of the natural flow regime as a "master variable" [21], it has become well recognized that environmental flows that retain the natural flow variability are essential to rebuilding and maintaining aquatic habitats, e.g., [22,23]. A spectrum of methods for defining environmental flows (e.g., hydrological, hydraulic, habitat simulation, and holistic) has been established, tested, and reviewed for their strengths and weaknesses under differing circumstances [24,25]. However, it has become equally recognized that managing for flows alone is not sufficient for achieving ecosystem restoration objectives, which also requires consideration of other parameters such as sediment and water quality, especially in severely disturbed river systems. For example, Kondolf advised that straightened, simplified channels need not only flow but also sufficient stream power and sediment load to erode and deposit and rebuild its channel complexity [26]. Wohl et al. (2015) noted the importance of considering temporal scale, the asynchronicity of sediment input and routing, and landscape context for including sediments in restoration, the last of which was highlighted as potentially dynamic across decades or centuries [27]. Arkle and Pilliod demonstrated through monitoring that 
restoring physical characteristics such as historic gradients may be critical to the ecological success of post-mining restoration projects [28]. Nonetheless, physical restoration of the channels or floodplains and environmental flow implementation have traditionally been practiced in silos, and flow releases typically lack explicit sediment considerations. This has led to limited restoration success and increasing recognition that all these actions will be necessary for the enhancement of heavily disturbed stream systems $[29,30]$.

Despite the presence of a wide range of 1- to 3-dimensional models that establish the connections among flows, physical changes, and habitat consequences, exploring the geomorphological and ecological consequences of flow scenarios to guide environmental restoration decision-making remains an extraordinary challenge for places where baseline data shortage has constrained the development of coupled models at the correct scales [31]. In general, there has been a lack of integrated models capable of simulating long-term (1-100 years) physical changes of large river systems that can simultaneously incorporate fine-resolution (e.g., daily) flow regimes instead of a steady discharge [32]. A majority of hydraulic models operate at the reach scale with fixed flow input due to high computational cost of simulating surface and channel flow processes [32]. To address these challenges, Landscape Evolution Models (LEMs) (e.g., SIBERIA, GOLEM, CHILD) have been developed since the late 1970s to simulate how interactions among climate, hydrology, fluvial, or slope processes influence the catchment and channel forms over large time scales [33,34]. As individual models become better established and more integrated with others, promising LEMs such as the CAESAR-LISFLOOD-FP model we chose for our study now have advanced capabilities to model increasingly complex processes (e.g., fluvial, slope, sediment) over varying spatial and temporal scales without extensive data requirements [32]. Similarly, habitat assessment models vary in degrees of complexity, from artificial neural networks with complex structures that require large amounts of data [35] to generalized methods such as those based on habitat suitability indices [36]. The latter have been commonly applied in large-scale modeling where habitat suitability assessment based on average characteristics is appropriate for study objectives, or when little field data is available, which is a severe challenge for our study [35].

In what follows, we introduce the study area, detail the methods applied to simulate the physical channel changes of the Lower Yongding River, and assess habitat suitability under the five flow scenarios. We then elaborate on the implications of the results for future research and practices of urban river ecological restoration.

\section{Methods}

We conducted a three-step sequence of hydrological analysis, landscape evolution modeling, and habitat suitability assessment (Figure 1) to explore the ecological ramifications of different flow scenarios for the lower Yongding River. First, we used the Indicators of Hydrologic Alteration (IHA) version 7.1 [37] and the adjusted Tennant method [38] to understand the historical flow regime and calculate various environmental flow discharges. Second, we applied the CAESAR-LISFLOOD-FP model version 1.9j to simulate long-term (i.e., ten years) landscape evolution under four environmental flow scenarios identified from step 1 and compared them with the flow replenishment plan proposed by the Beijing Water Science and Technology Institute (BWSTI). Finally, we used the Combined Suitability Index (CSI) and Weighted Usable Area (WUA) [39] method to assess the amount and distribution of suitable fish habitat and compare the ecological effects of all five flow scenarios.

IHA is a software program developed by Nature Conservancy in the 1990s that assesses 67 ecologically relevant hydrological parameters. It is one of the most commonly applied methods to help understand the hydrologic and ecological impacts of various disturbances [40]. 


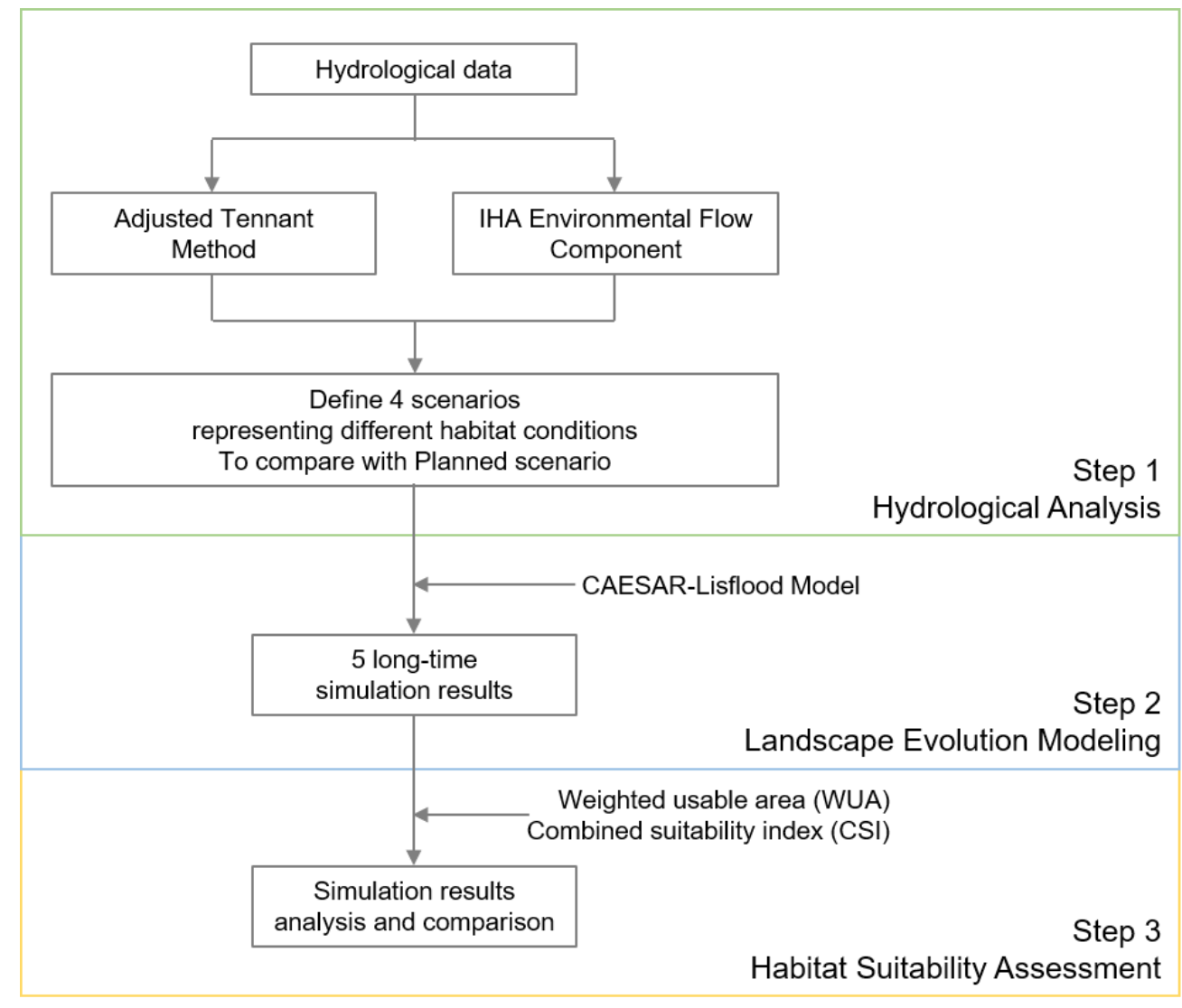

Figure 1. The modeling process.

The Tennant method developed in the 1970s is a broadly applied ecological flow assessment (EFA) method that uses predetermined percentages of average annual flow (AAF) as ecological flow criteria [41]. As one of the oldest hydrological approaches for EFA, it does not require extensive data and is of lower complexity than other more sophisticated approaches, such as the hydraulic, habitat simulation and holistic approaches [25]. However, because the Lower Yongding River had remained dry for four decades and flow replenishment had only occurred for two and a half years by November 2021, with limited ongoing monitoring, the severe shortages of hydrological, hydraulic, and ecological data precluded the use of more complex EFA approaches. Additionally, previous research on the upstream valley section deemed the EFs assessed by the Tenant method appropriate by comparing them with six other hydrological and hydraulic methods, including the low flow index, Texas Method [42], $Q_{90}$ and $Q_{50}$ of flow duration curve, Wetted-Perimeter method, and the R2Cross method [43].

The CAESAR-LISFLOOD-FP model is an integration of the well-established CAESAR (Cellular Automaton Evolutionary Slope and River) Landscape Evolution Model developed in the early 2000s [44,45] and the LISFLOOD-FP hydraulic model [46]. We selected C-L due to its advanced abilities and computational efficiency in simulating large-scale river corridors (1-100 km²) over a long period (1-100 years) [34]. It can simulate both lateral channel changes and sediment erosion and deposition processes in catchments and reaches over varying spatial and temporal scales. Additionally, C-L can efficiently incorporate flow regimes at up to daily resolution instead of a steady discharge. Its ability to estimate erosion and deposition also allows the direct application of widely adopted habitat assessment methods such as the Combined Suitability Index (CSI) method introduced below.

The CSI method was developed in the 1980s and has been widely applied to quantify the suitability of a given habitat for a species of interest, based on habitat suitability curves (HSCs) that relate physical habitat characteristics to species' preferences [39,47]. The weighted usable area (WUA) is an area-weighted habitat suitability index indicative of 
instream habitat availability for the chosen species [48]. CSI and WUA were chosen due to the severe lack of baseline ecological data.

Below we introduce the area of interest and elaborate on the specific methods applied at each step.

\subsection{Study Area}

Our study area is a $48 \mathrm{~km}$-long downstream segment of the Yongding River $\left(112-117^{\circ} 45^{\prime} \mathrm{E}\right.$, $39-41^{\circ} 20^{\prime} \mathrm{N}$ ) (Figure 2). The entire YDR is $747 \mathrm{~km}$ long, with a drainage area of $47,016 \mathrm{~km}^{2}$. It flows from the west to the east across three provinces into Beijing at the Guanting Reservoir (Beijing's largest reservoir built in 1951) and drains into the Bohai Bay in Tianjin (Figure 2). The YDRB is in a semi-humid and semi-arid climate transition zone, with annual average temperatures ranging between $5.1-7.1^{\circ} \mathrm{C}$ and annual average precipitation of $\sim 400 \mathrm{~mm}$. The climate features a strong seasonality, with $70-80 \%$ of its rainfall occurring in summer from June to August.

The Yongding River Beijing segment is $170 \mathrm{~km}$ long, draining $3168 \mathrm{~km}^{2}$ of land and accounting for $6.7 \%$ of YDRB. This $170-\mathrm{km}$ segment can be divided into three sections (Figure 2a): (1) the valley section $(91.2 \mathrm{~km})$ from Guanting Reservoir to Sanjiadian gauging station; (2) the city section $(18.4 \mathrm{~km})$ from Sanjiadian to Lugouqiao gauging station, and (3) the suburban section $(59.8 \mathrm{~km})$ from Lugouqiao to Beijing's south administrative boundary. For the valley section, long-standing agricultural practices and reservoir operations since 1951 have been the primary factors influencing the river channel. For the city and suburban sections, reduced streamflow, groundwater depletion, limited precipitation, and loss of stormwater to drainage networks have led to the channel becoming perennially dry since the 1980s (Figure 2c,d) [49]. Subsequently, agricultural uses expanded, and new recreational uses occurred within or adjacent to the channel. For example, during 2005-2008, certain riverine villages took advantage of legal loopholes and rented their properties to developers, causing at least five golf courses to be built entirely or partially within the channel [50].

In 2009, the Beijing government began to revitalize the city section and, by 2014, constructed five in-channel public parks through various strategies such as sewage interception, flow replenishment, seepage control, and reuse of reclaimed water [51]. For example, the Beijing Garden Expo Park at the south end of this section, the 2013 Garden Expo site, transformed a 30-m-deep sandpit into a 35-hectare wetland and 69 sub-gardens that showcased international and national garden cultures.

Our chosen study reach is the $48 \mathrm{~km}$-long, 69.30- $\mathrm{km}^{2}$ lower part of the suburban section, extending from Wanping Lake to Beijing's southern border (Figure 2). Since the reach dried up in the 1980s, in-channel agricultural uses first increased, but then decreased after 2005 due to riparian greening efforts that have continued to date. As noted above, partially forested golf courses were built during 2005-2008 in the name of greening, increasing forests and lawns (Figure 3). The channel remained dry until 2019. As the study reach became one of the critical ecological restoration areas of the General Plan mentioned in Section 1, exploratory flow replenishment began in 2019. A total of 132 million $\mathrm{m}^{3}$ (Sanjiadian Station) of water was released in 2019, lasting for 54 days from April to June, primarily at a rate of $10 \mathrm{~m}^{3} / \mathrm{s}$ and occasionally at $20 \mathrm{~m}^{3} / \mathrm{s}$ (for 7 days during 5/18-5/24), $30 \mathrm{~m}^{3} / \mathrm{s}$ (for 4 days during 5/25-5/28), and $60 \mathrm{~m}^{3} / \mathrm{s}$ (for 1 day on 6/6). In 2020, flow release occurred for 24 days from April to May, totaling 210 million $\mathrm{m}^{3}$. Two high flow events up to the 3-year return period flow $\left(380 \mathrm{~m}^{3} / \mathrm{s}\right)$ were released on $5 / 8$ and $5 / 14$, each for a full day, while the average discharge was maintained at $70 \mathrm{~m}^{3} / \mathrm{s}$ for all other times.

The dire ecological conditions before flow replenishment, representativeness of drying urban streams in northern China, and ongoing rehabilitation efforts make Yongding River a natural laboratory for experimenting with flow restoration strategies to achieve longterm ecological enhancement. Although field monitoring is underway to investigate the ecological effects of early replenishment, modeling approaches are urgently needed to inform future flow distribution before monitoring outcomes are available. 

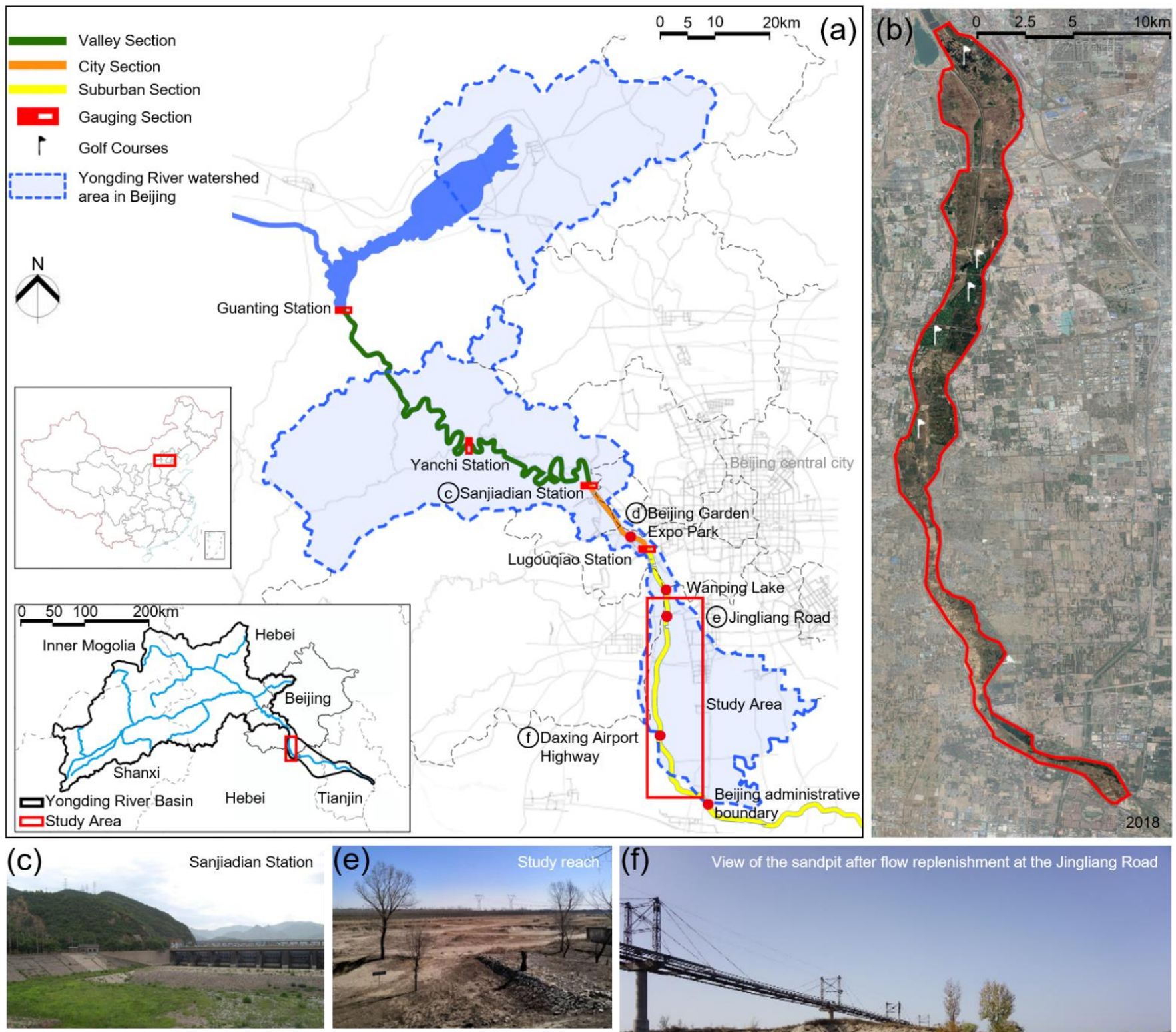

(d)
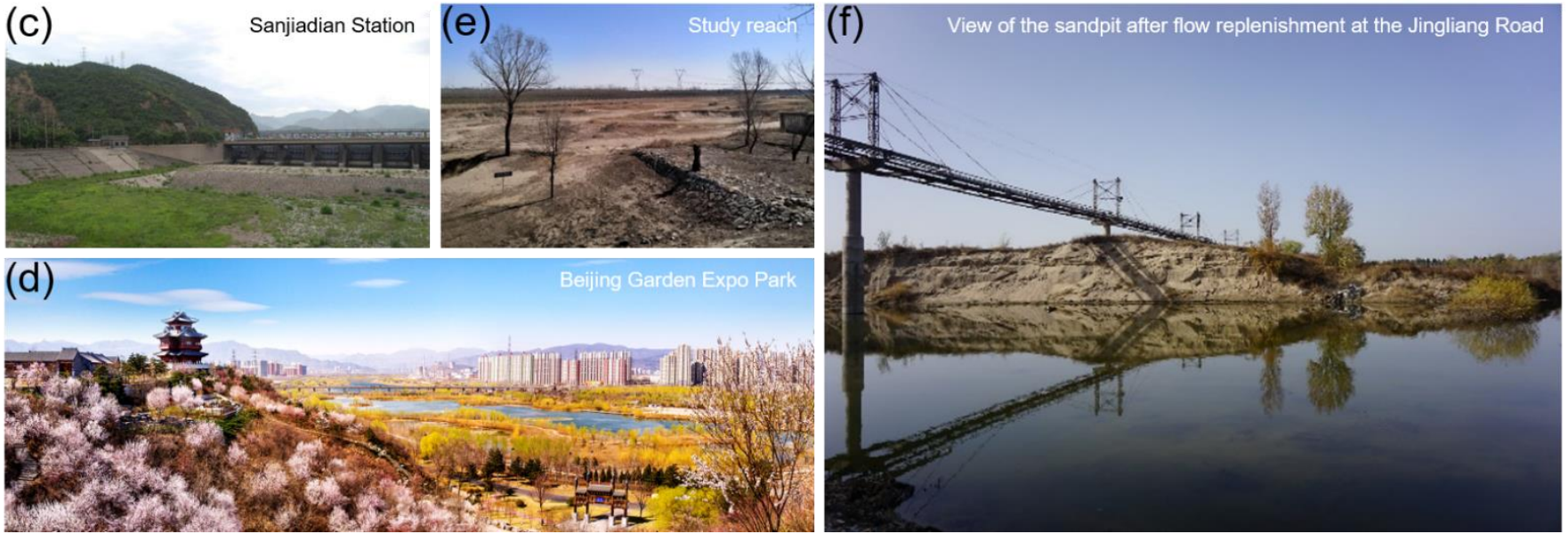

Figure 2. Context of the lower Yongding River, Beijing, China: (a) study area location in Beijing, YDRB, and the country; (b) study area 2018 aerial photo; (c) the Sanjiadian Station; (d) Beijing Garden Expo Park; (e) dry channel near the Daxing Airport Highway (before flow release); (f) in-channel sandpit at Jingliang Road (after flow release). (Photo sources: c-http: / /blog.sina.com.cn/s/blog_447e88bb0100k7nr.html (accessed on 30 October 2021); d-http:/ / www.gardenexpo-park.com/ (accessed on 30 October 2021); (e,f) by Author 1). 


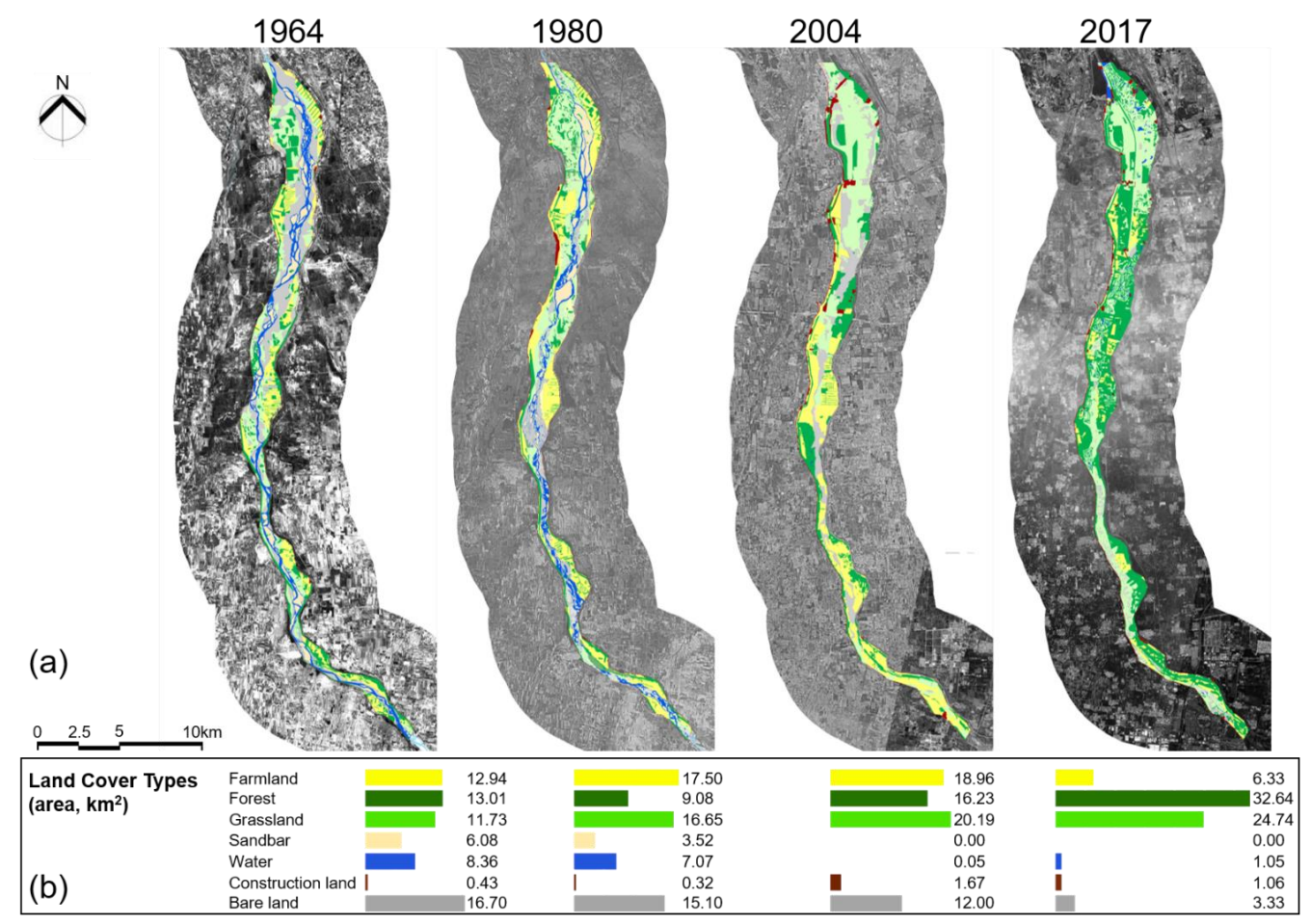

Figure 3. Evolution of the study area from 1964 to 2017 as seen from the aerial photos (a) and measured by land cover changes (b).

\subsection{Characterizing Historical Flow Regime}

To understand the historical flow regime under which the aquatic ecosystem had evolved, we first used IHA to quantify critical environmental flow components (EFC). IHA is a software program that assesses 67 ecologically relevant hydrological parameters to help understand the hydrologic and ecological impacts of various disturbances [37]. Because the flow regime became heavily regulated after the Guanting Reservoir was built in 1951, we selected the earliest streamflow records from 1920-1951 (water year, WY) as the reference flow regime. More specifically, after examining all the flow data available at the four gauging stations, i.e., Guanting, Yanchi, Sanjiadian, and Lugouqiao (Figure 2), we selected the Sanjiadian Station $\left(116^{\circ} 06^{\prime} \mathrm{E}, 39^{\circ} 58^{\prime} \mathrm{N}\right)$ with the highest data integrity as the primary data source. Daily flow records for WY 1920-1949 and monthly records for WY 1950-1951 were subject to IHA to calculate five EFC parameters, including extreme low flows, low flows, high flow pulses, small floods, and large floods (Figure 4a).

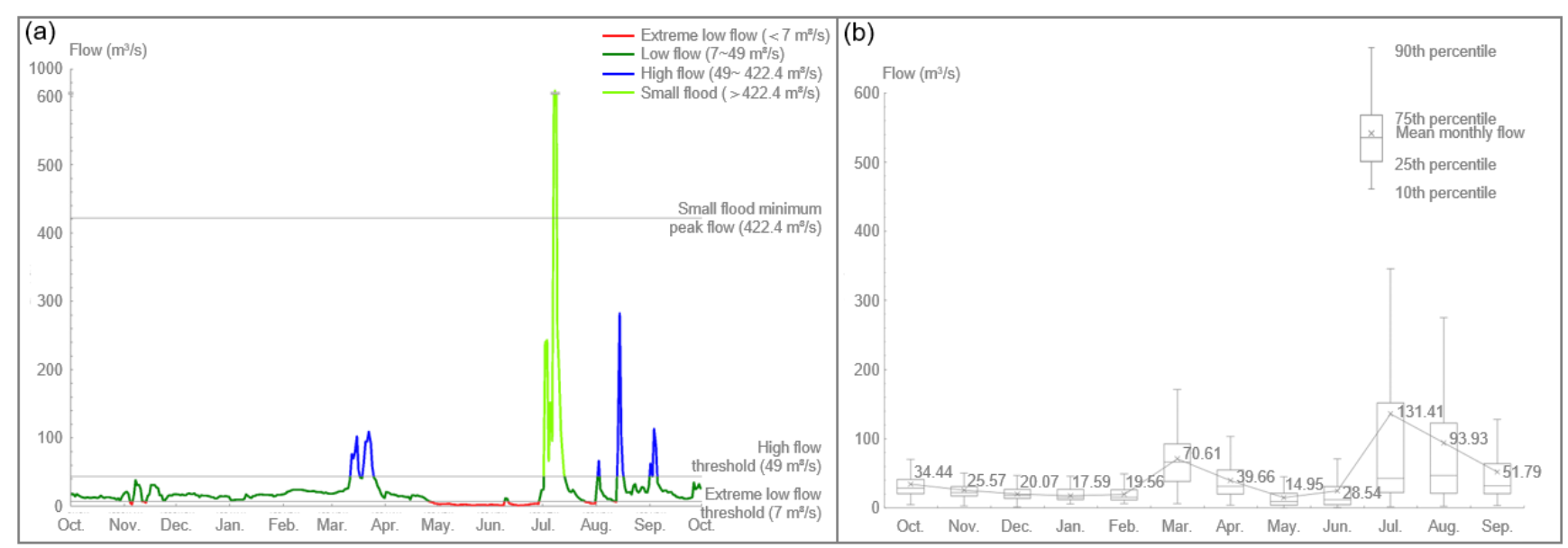

Figure 4. (a) the five environmental flow components identified by IHA for the Sanjiadian Station illustrated with the example year (1931 WY) hydrograph; (b) distribution of average monthly flows, Sanjiadian, Beijing (1920-1951). 
The IHA calculation indicated that the range of extreme low flows was $0-7 \mathrm{~m}^{3} / \mathrm{s}$, low flow was 7-49 m³ $/ \mathrm{s}$, high flow was $49-422.4 \mathrm{~m}^{3} / \mathrm{s}$, small floods was $422.4-2160 \mathrm{~m}^{3} / \mathrm{s}$, and large flood was $>2160 \mathrm{~m}^{3} / \mathrm{s}$. Using WY 1931 as an example, Figure 4a illustrated a representative annual streamflow regime featured by a distinct seasonality. Historically, the long low-flow season typically lasted from September to March, with subsequent brief spring high-flow events in March. The low flows then decreased into extreme low flows until the summer storms arrived. Pulses of massive floods and high flows, intermingled with low flows in between, featured the summer months of July and August. The 1920-1951 historical records also showed that high flows occurred in March, July, and August, about twice a year on average, whereas small floods mainly occurred in July and August once every two years. In wetter years, when small floods occurred, the high-flow season could start as early as June and last until the end of September.

\subsection{Identifying Flow Scenarios}

To explore how various environmental flow scenarios may affect long-term channel geomorphology, we obtained the flow replenishment plan (aka "PLAN") developed by BWSTI [52] and compared it with four continuous flow scenarios (S1-S4) developed with the modified Tennant method [38] (Table 1).

Table 1. The environmental flows representing different habitat conditions.

\begin{tabular}{|c|c|c|c|c|c|c|c|c|c|c|c|c|c|c|}
\hline \multirow{3}{*}{$\begin{array}{c}\text { Aquatic } \\
\text { Habitat } \\
\text { Condition }\end{array}$} & \multicolumn{14}{|c|}{ Monthly Environmental Flow (m³/s) } \\
\hline & \multicolumn{8}{|c|}{ Dry Season } & \multicolumn{6}{|c|}{ Wet Season } \\
\hline & $\%$ of MMF & Oct. & Nov. & Dec. & Jan. & Feb. & Mar. & $\%$ of MMF & Apr. & May. & Jun. & Jul. & Aug. & Sep. \\
\hline $\begin{array}{l}\text { S1-Optimum } \\
\text { (MMF) }\end{array}$ & $100 \%$ & 34.44 & 25.57 & 20.07 & 17.59 & 19.56 & 70.61 & $100 \%$ & 39.66 & 14.95 & 28.54 & 131.41 & 93.93 & 51.79 \\
\hline S2-Excellent & $30 \%$ & 10.33 & 7.67 & 6.02 & 5.28 & 5.87 & 21.18 & $50 \%$ & 19.83 & 7.48 & 14.27 & 65.71 & 46.97 & 25.90 \\
\hline S3-Fair & $10 \%$ & 3.44 & 2.56 & 2.01 & 1.76 & 1.96 & 7.06 & $30 \%$ & 11.90 & 4.49 & 8.56 & 39.42 & 28.18 & 15.54 \\
\hline S4-Poor & $10 \%$ & 3.44 & 2.56 & 2.01 & 1.76 & 1.96 & 7.06 & $10 \%$ & 3.97 & 1.50 & 2.85 & 13.14 & 9.39 & 5.18 \\
\hline
\end{tabular}

Specifically, BWSTI's PLAN proposes a total annual replenishment volume of 260 million $\mathrm{m}^{3}$ (at Sanjiadian). It sets the monthly average flows to $15 \mathrm{~m}^{3} / \mathrm{s}$ in March-May, $7 \mathrm{~m}^{3} / \mathrm{s}$ in June-September, and $11 \mathrm{~m}^{3} / \mathrm{s}$ in October, and proposes two high-flow events in spring and autumn with a discharge of $60 \mathrm{~m}^{3} / \mathrm{s}$ or higher for 3-5 days [19].

The four continuous flow scenarios we developed with the modified Tennant method represent four different habitat conditions: optimum, excellent, fair, and poor. Because the constant use of the mean annual flow (MAF) in the original Tennant method [41] cannot reflect the substantial monthly flow variability of the Yongding River, we replaced the MAF with mean monthly flows (MMFs) [38] calculated with Sanjiadian's 1920-1951 flow records (Figure $4 \mathrm{~b}$ ). Monthly environmental flows were then calculated based on the predetermined percentages of MMFs for winter (October-March) and summer (April-September) [41] to represent the four specified habitat conditions (Table 1). The total annual flow volumes estimated for historical conditions, those actually released in 2019 and 2020, proposed by PLAN, and required for the other four flow scenarios are listed in Table 2.

\subsection{Modeling Landscape Evolution with CAESAR-Lisflood}

As mentioned above, the C-L model integrates the CAESAR Landscape Evolution Model $[44,45]$ and the LISFLOOD-FP hydraulic model [46]. CAESAR simulates landscape changes by routing water and sediments through a grid of cells and updating cell elevations based on calculations of erosion and deposition of each cell [44,45]. It does so by integrating four sub-models, i.e., a hydrological model, the flow model, fluvial erosion and deposition, and slope processes. The LISFLOOD-FP model is a raster-based low-complexity hydraulic model, which simplifies the computation by decoupling flows in the $\mathrm{x}$ and $\mathrm{y}$ directions and treating the 2D problem as a series of 1D calculations through the cell face boundaries [46]. In C-L, the flow is simulated exclusively by LISFLOOD-FP. 
Table 2. Total flow volumes needed for various flow scenarios.

\begin{tabular}{ccc}
\hline Flow Conditions & $\begin{array}{c}\text { Total Flow Volume } \\
\text { (Million } \mathbf{~ m}^{\mathbf{3}} \text { ) }\end{array}$ & $\begin{array}{c}\text { Cost of Flow Replenishment } \\
\text { (Million RMB) }\end{array}$ \\
\hline 1964 & 792 & Not applicable \\
1980 & 519 & Not applicable \\
2019 actual & 132 & 330 \\
S4-Poor & 150 & 375 \\
2020 actual & 210 & 525 \\
PLAN by BWSTI & 260 & 650 \\
S3-Fair & 340 & 850 \\
S2-Excellent & 630 & 1575 \\
S1-Optimum (MMF) & 1450 & 3625 \\
\hline
\end{tabular}

${ }^{1}$ Note: Cost of flow replenishment estimated based on $2.5 \mathrm{RMB}$ per $1 \mathrm{~m}^{3}$ water [53].

C-L can be run in two modes, catchment and reach. The catchment mode has a single water influx, the rainfall, while the reach mode allows water and sediment to enter from one or more locations of the reach. The required inputs of C-L include a Digital Elevation Model (DEM), sediment grain size distribution, flow influx (reach mode), and Manning's $n$ roughness coefficients throughout the study area. Major model outputs include bed elevation, flow depth, and velocity for each cell at each timestep, sediment grain size distribution, and net erosion and deposition for the entire study area [44].

To set up the C-L model, we first used ArcMap to process 51,774 point elevations measured in 2016 and generate a DEM for terrain representation. Due to the limits of C-L's computational capacity, a maximum of $1000 \times 1000$ grids is allowed for the entire modeling area. Therefore, we used $50 \times 50 \mathrm{~m}$ as the DEM resolution that resulted in a total of $842 \times 219$ grids. Echoing other studies that used the same resolution [54,55], we considered $50 \times 50 \mathrm{~m}$ appropriate for our primary focus of exploring the long-term evolution of the study reach. To simulate sediment transport, we used the grain size distribution data supplied by BWSTI based on their field measurements in 2019. Besides, a spatially explicit Manning's $n$ roughness coefficients table was developed based on existing vegetation conditions to account for the effects of vegetation on fluvial processes. Test runs indicated that the model required 175-210 days to spin up, so the calibration process below focused on examining model outputs after this initial period.

Due to the significant modification to channel morphology since the 1980s and the absence of detailed historical topographical data, we used aerial photographs in June 2020 after the flow replenishment to calibrate the C-L model (Figure 2f). Specifically, we used the 2019 DEM and the actual replenishment discharges as the model input and compared the simulated wetted areas with those interpreted from the 2020 aerial photographs. The Producer's Accuracy $[56,57]$ was then used to evaluate how frequently the simulated wetted areas were correctly shown on the classified map. Through iterative calibration and verification processes, nine critical factors recommended by Ziliani et al. [58], including lateral erosion rate, number of passes for edge smoothing filter, max erode limit, min time step, $\min Q$ for depth calculation, water depth above which erosion can happen, suspended sediment load, bedload solid transport formula, and vegetation critic shear (see specific parameter settings in Table S1, Supplementary Material), were set at values appropriate for the specific spatial and temporal resolutions of this study. Like many other fluvial geomorphic studies, the calibration was qualitative in nature due to severe data limitations but remained critical to improving the model accuracy. The final Producer's Accuracy value was $87 \%$, exceeding the commonly recommended $85 \%$ target $[59,60]$. Besides, during calibration runs, the model spin-up time stayed within 175-210 days, so we used 210 days as the final spin-up period.

The five flow scenarios identified in Section 2.3 were subsequently simulated in C-L for ten years after the 210-day spin-up period. Monthly outputs of flow velocities and water depths from the 10th year, bed level changes, and net sediment transport volume at the end of the run were directly exported from C-L. Monthly wetted areas, surface water widths, 
and elevations were calculated from water depths and bed elevation changes. All the above parameters were then compared among the five scenarios to synthesize the range of channel geomorphic changes. Additionally, surface water widths were compared to those estimated from the 1964 and 1980 aerial photos to understand how the physical channel forms under the flow scenarios compared to historic conditions. For ease of communication, the study area was divided into six reaches (1-6) based on the locations of bridges.

\subsection{Habitat Assessment}

As previously mentioned, we adopted the classical indicators of the Combined Suitability Index (CSI) and Weighted Usable Area (WUA) for habitat assessment due to the lack of baseline ecological data [39]. The selection of species of interest was based on a literature review. Additionally, we calculated the Hydraulic Habitat Suitability Index (HHS) to eliminate the size effect of different wetted areas. We specify the methods in detail as follows.

Based on habitat suitability curves that use water depth, velocity, and channel index conditions (substrate and cover) as the primary physical characteristics of stream habitats, we use the formula below to calculate the CSI of a given cell. Water depths and flow velocities are direct outputs of C-L, and $S_{i}$ has a constant value of 1 in our case due to the substrate being sand. CSI varies between $0 \sim 1$, with 0 representing unsuitable and 1 most suitable for the given species [61]. CSI values between 0.6-1.0 can be classified as high suitability, $0.3-0.6$ as medium suitability, and $0.1-0.3$ as low suitability [62].

$$
\mathrm{CSI}_{i}=V_{i} \times D_{i} \times S_{i}
$$

where: $V_{i}=$ suitability associated with velocity in cell $i$;

$D_{i}=$ suitability associated with depth in cell $i$;

$S_{i}=$ suitability associated with channel index in cell $i$.

Because the study reach remained perennially dry between the 1980s and 2019, we relied on reviewing literature and historical records to select the species of interest. According to Zhou [63], who compared historical records with a 2016 survey, the dominant fish species of the Yongding River Beijing segment, both historically and in the recent past, belong to the Cyprinidae family, which accounts for $50 \%$ of the total number of fish species. Specifically, Carassius auratus is the most frequently occurring species for the entire Beijing segment, while Opsariichthys bidens and Hemiculter leucisculus are also common in the valley and city/suburban sections, respectively. All three species are native to the region, with Carassius auratus and Hemiculter leucisculus being highly tolerant of urbanized conditions. Due to the absence of published habitat suitability curves for Opsariichthys bidens and Hemiculter leucisculus, we selected Carassius auratus as the indicator species and used suitability curves developed by Li et al. [64] (Figure 5) to calculate CSI for each cell. It should be noted that the channel's perennial dry conditions during the past four decades precluded the development of more accurate curves based on local field surveys. For the same reason, restoring habitat for dominant fish fishes is in itself an extraordinary challenge with $\sim 560$ reservoirs, numerous dams, and $\sim 160$ pollution discharge points in the YDRB [63]. Therefore, we consider the above methods of selecting indicator species and suitability curves appropriate for the purpose of this study.
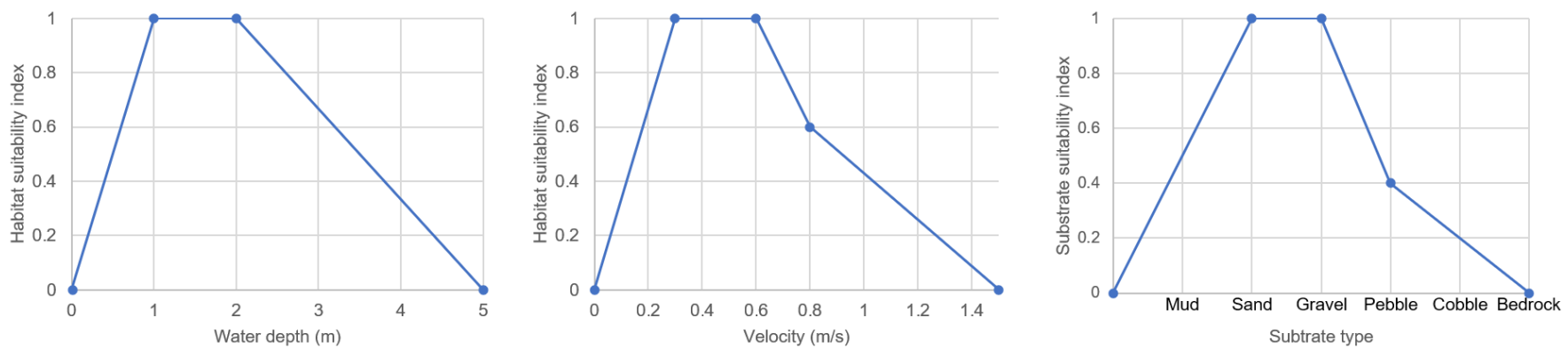

Figure 5. Habitat suitability curves for Carassius auratus based on Li et al. [64]. 
Building upon the calculations of CSI above, the weighted usable area (WUA), i.e., the area-weighted habitat suitability index [48], is calculated as:

$$
W U A=\sum_{i=1}^{n} A_{i} \times C S I_{i}
$$

where: $A_{i}$ is the surface area of cell $i$, and

$\mathrm{CSI}_{i}$ is the composite suitability of cell $i$.

Once WUA is determined, the hydraulic habitat suitability index (HHS) is computed by dividing WUA by the total wetted area [62], eliminating the size effect of different wetted areas under various flow scenarios. HHS varies from 0 to 1 .

\section{Results}

\subsection{Wetted Area and Surface Water Width}

Calculated from direct water depth outputs of C-L, the monthly average wetted areas in the 10th year showed minor changes across the five scenarios (Figure 6). S4 showed the overall largest wetted area $\left(\right.$ mean $\left.=16.65 \mathrm{~km}^{2}\right)$, while S1 showed the smallest $\left(\right.$ mean $\left.=15.68 \mathrm{~km}^{2}\right)$ (Table S2). The largest monthly wetted area appeared in July for S1-S4 and March for PLAN, whereas the smallest occurred in February for S2, S3, PLAN, and May for S1 and S4. The largest intra-annual change in wetted areas, based on the difference between the maximum and minimum wetland areas, occurred in $\mathrm{S} 2\left(2.50 \mathrm{~km}^{2}\right)$, whereas the smallest occurred in $S 4\left(1.11 \mathrm{~km}^{2}\right)$.

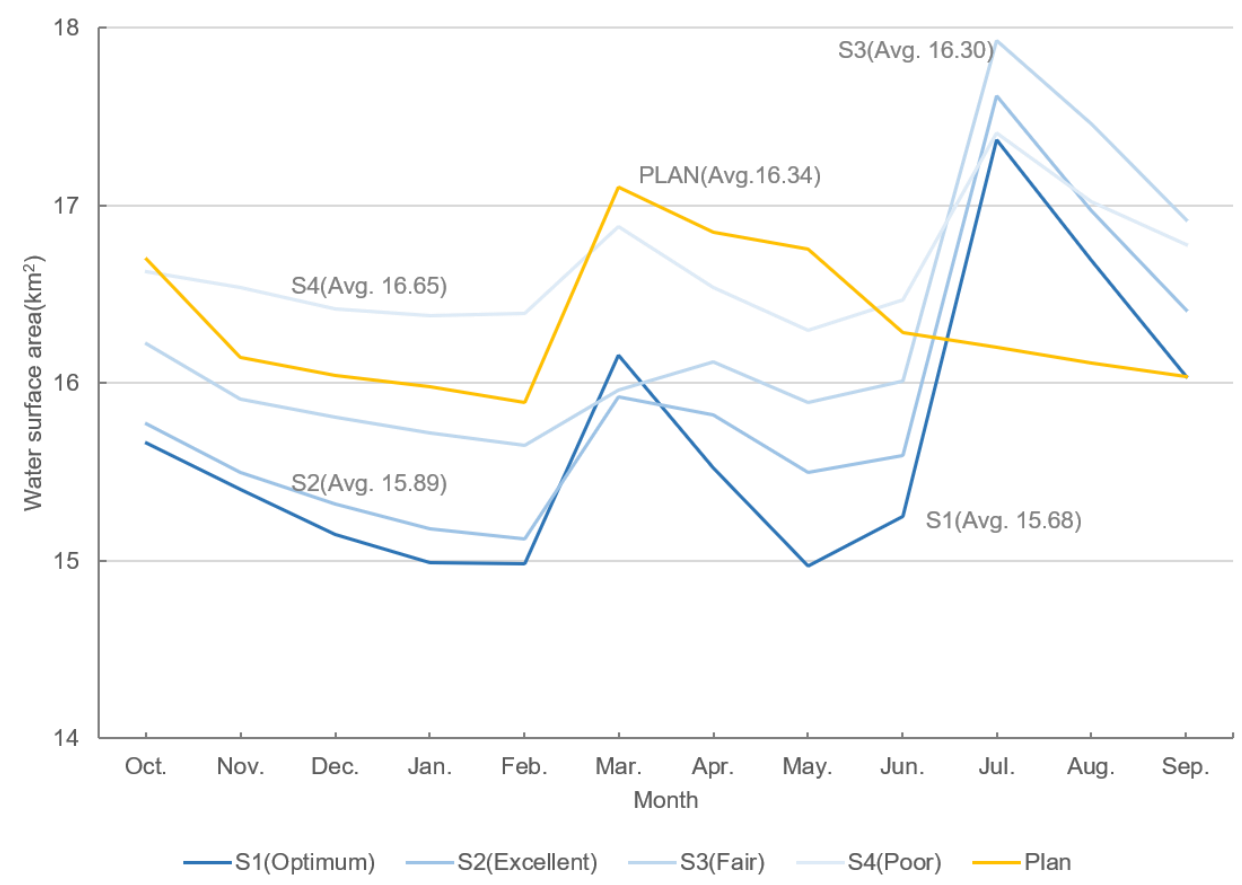

Figure 6. Monthly average water surface areas during the 10th year under the five scenarios.

Next, we compared surface water widths of the five scenarios with historical conditions depicted in aerial photos of 1964 and 1980 taken in summer (June-August). Because the specific months when the aerial photos were taken were unknown, we calculated the three-month averages of surface water widths of the five scenarios in Year 10 (Table S3). The average surface water width of the entire study area during summer varied from $304.7 \mathrm{~m}$ (PLAN) to $339.8 \mathrm{~m}$ (S3), a substantial increase from 1964 and 1980 (149.5 m-189.3 m). Except for Reach 3, water widths in all other reaches generally increased in the five scenarios than 1964/1980 (Figure 7b). The narrower channel width in Reach 3 was likely contributed to by riparian greening efforts during 2012-2015 that had confined the banks. The most 
significant changes occurred in reaches 2 and 6 due to the large sandpit in the former and expansive farmland in the latter.

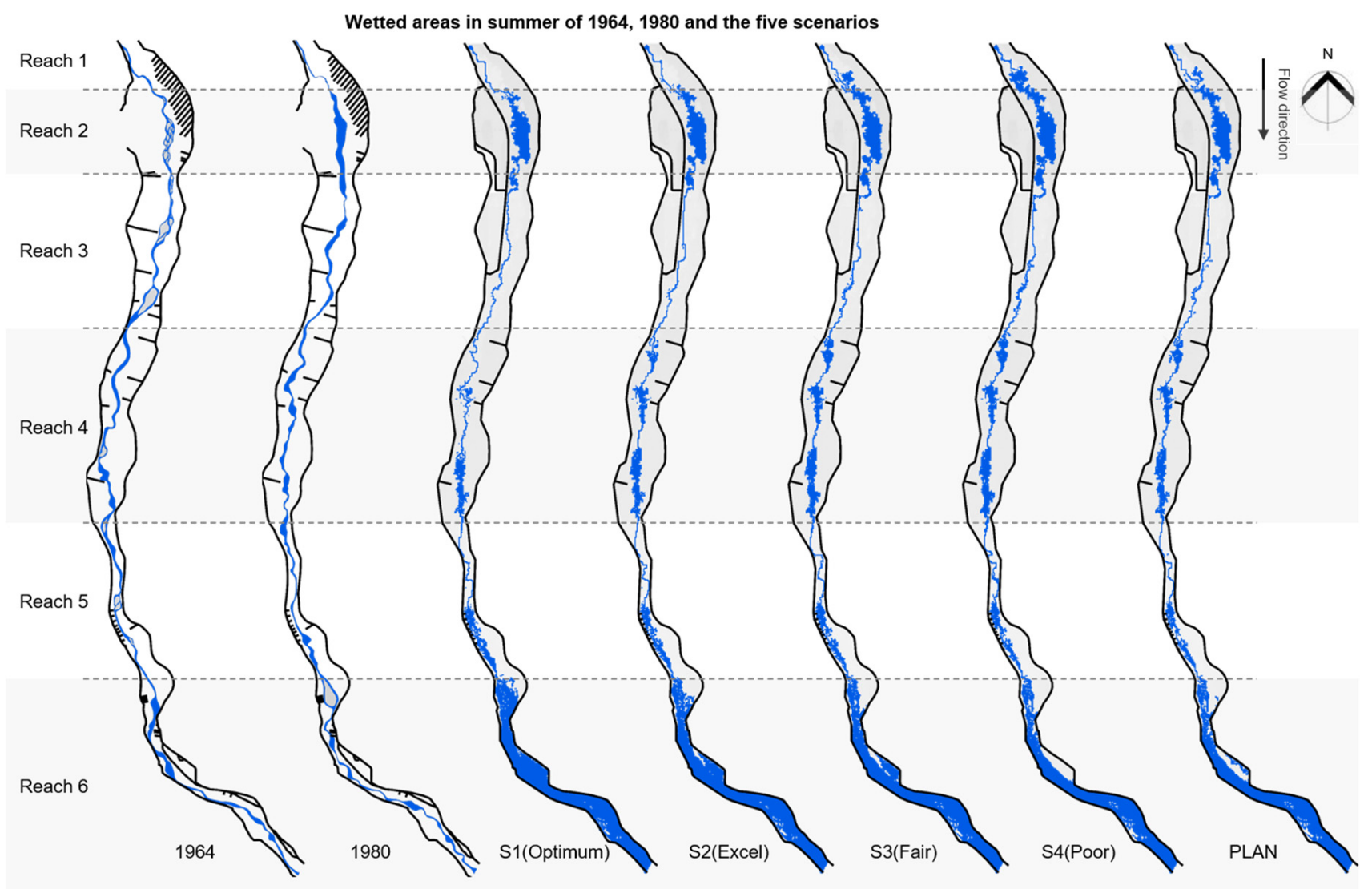

(a)
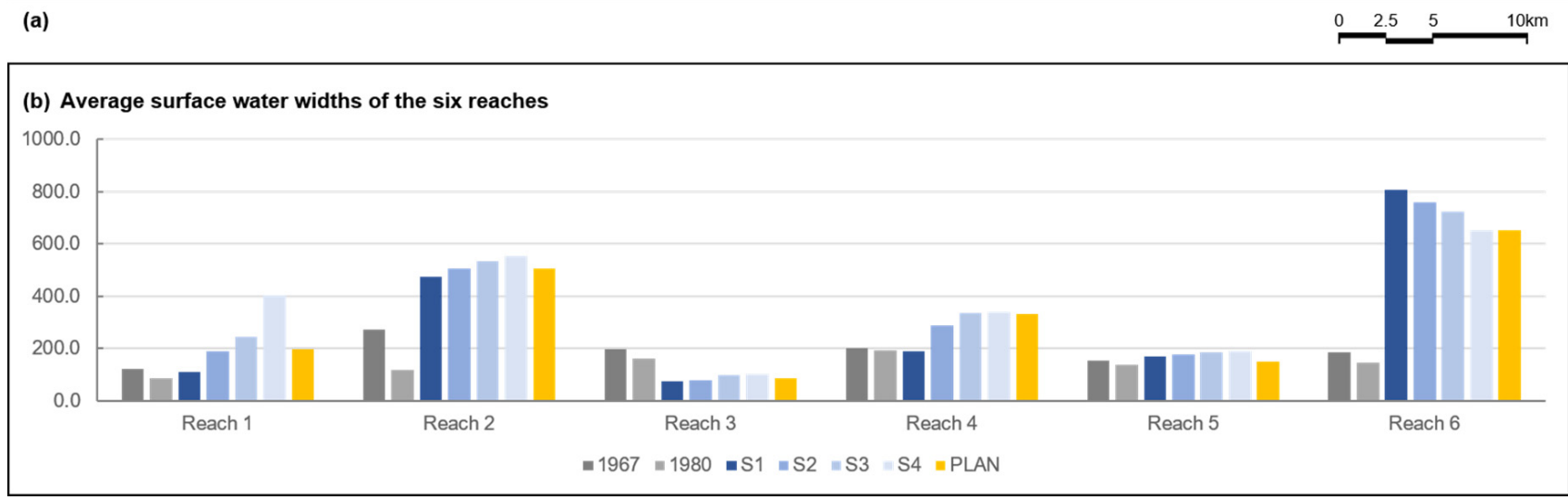

Figure 7. Average surface water widths during summer in selected scenarios compared to 1964 and 1980.

\subsection{Water Depth}

Calculated based on direct daily water depth outputs of C-L, the distribution of water depths in the 10th year showed that the $0-1 \mathrm{~m}$ class occurred the most frequently for all five scenarios (25.0-30.0\%) (Table S4). The 1-2 m class most suitable for Carassius auratus also occurred often (20.4-23.6\%). S4 showed the largest mean water depth $(2.7 \mathrm{~m})$, whereas PLAN showed the smallest $(2.4 \mathrm{~m})$. The maximum water depth $(12.9-13.9 \mathrm{~m})$ occurred in Reach 2 at the sandpit for all scenarios (Figure 8). The general decrease of maximum depth from S4 to S1 can be explained by higher flows exhibiting a stronger capacity to scour out a deeper channel at the southern end of the sandpit, leading to less water being stored in the sandpit. 


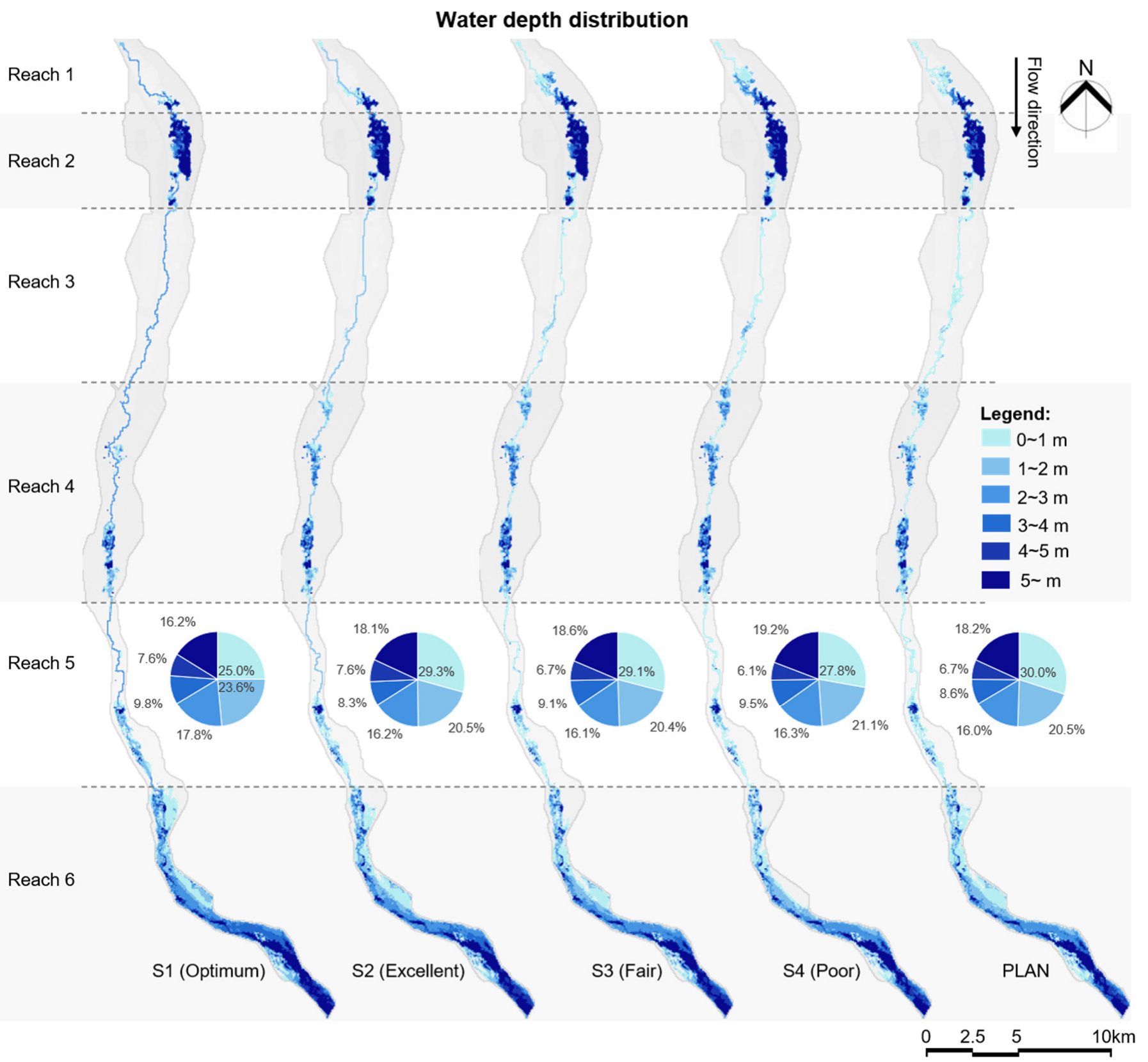

Figure 8. Distribution of average water depths during the month where maximum depth occurred (July for S1-S4, March for PLAN).

\subsection{Flow Velocity}

Based on daily flow velocity outputs within the 10th year, the highest average flow velocity across the study area occurred in July for S1-S4, as opposed to March during the longer $60 \mathrm{~m}^{3} / \mathrm{s}$ high-flow event for the PLAN scenario. Figure 9 and Table S5 showed the velocity distribution of the respective month when the highest average velocity occurred. The $0-0.5 \mathrm{~m} / \mathrm{s}$ class happened the most frequently for all scenarios $(88.5-96.7 \%)$, whereas the $1-1.5 \mathrm{~m} / \mathrm{s}$ class happened the least frequently and only in S1, S2, and PLAN (0.4-1.2\%). The maximum flow velocity of the scenarios ranged from $0.8 \mathrm{~m} / \mathrm{s}$ (S4) to $1.3 \mathrm{~m} / \mathrm{s}$ (PLAN), unlikely to affect the channel's stability. High-velocity $(>0.5 \mathrm{~m} / \mathrm{s})$ areas were mainly located within Reach 1 at the northern end and Reach 3 in the middle. 


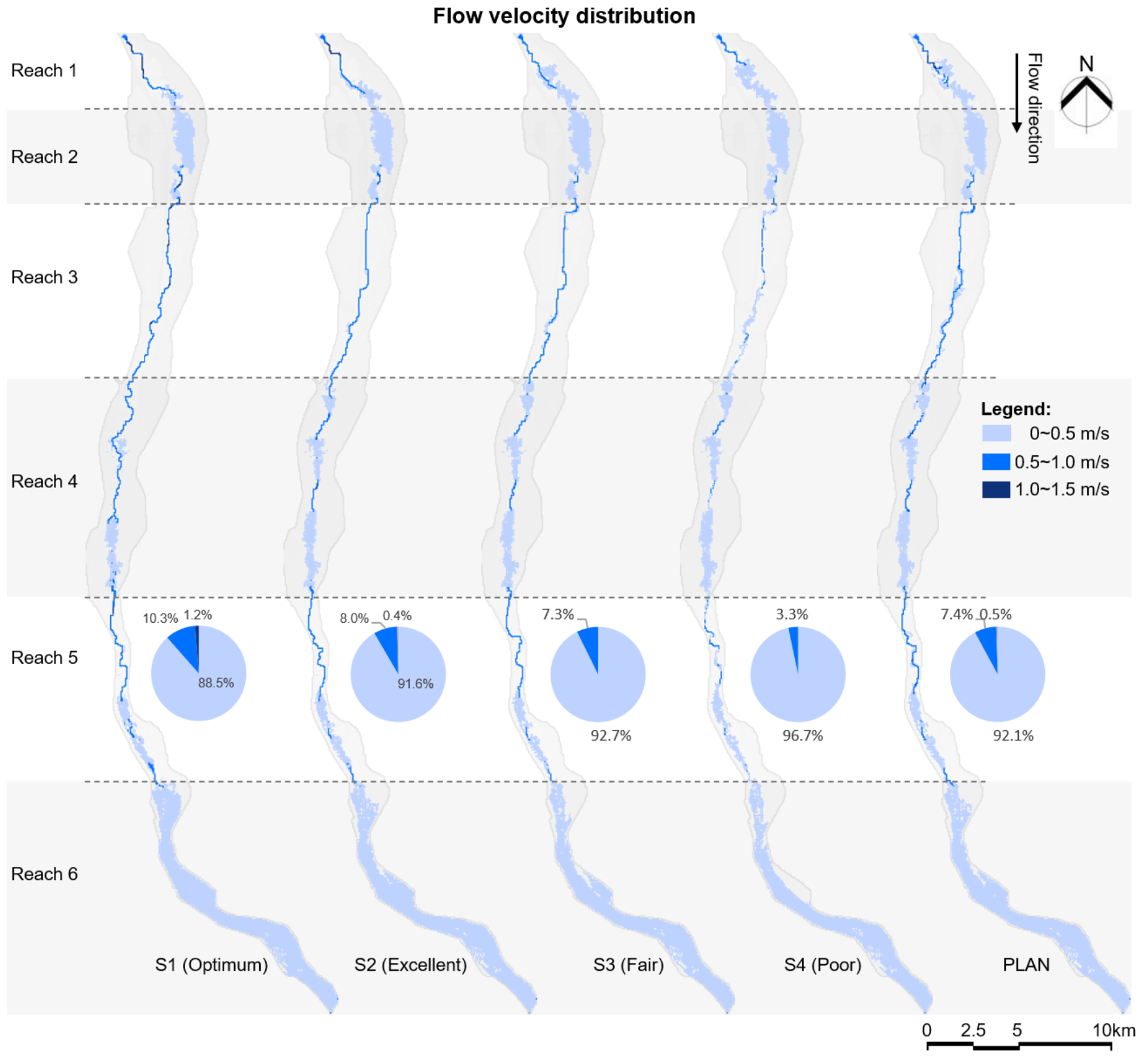

Figure 9. Flow velocity distribution when the highest average velocity occurred (i.e., July for S1-S4 and March for PLAN).

\subsection{Bed Level Changes}

The elevation changes in the channel fell mostly within $-0.1-+0.1 \mathrm{~m}(86.8-92.9 \%)$ across all scenarios (Table S6). S1 incurred the most change, with $5.4 \%$ of the channel area exceeding $1 \mathrm{~m}$ of absolute elevation change, whereas S4 had the least $(1.6 \%)$. The erosion areas were mainly distributed along the primary channel, while deposition mostly occurred in the floodplain (Figure 10a). Sediment transport volume decreased from S1 to $\mathrm{S} 4$ as flow discharge decreased, with the volume in $\mathrm{S} 4\left(0.7 \times 10^{3} \mathrm{~m}^{3}\right)$ only amounting to $6.5 \%$ of S1. However, the PLAN scenario incurred slightly higher sediment transport than

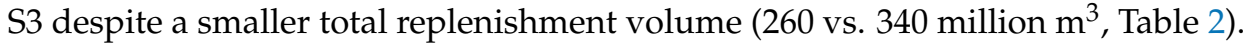




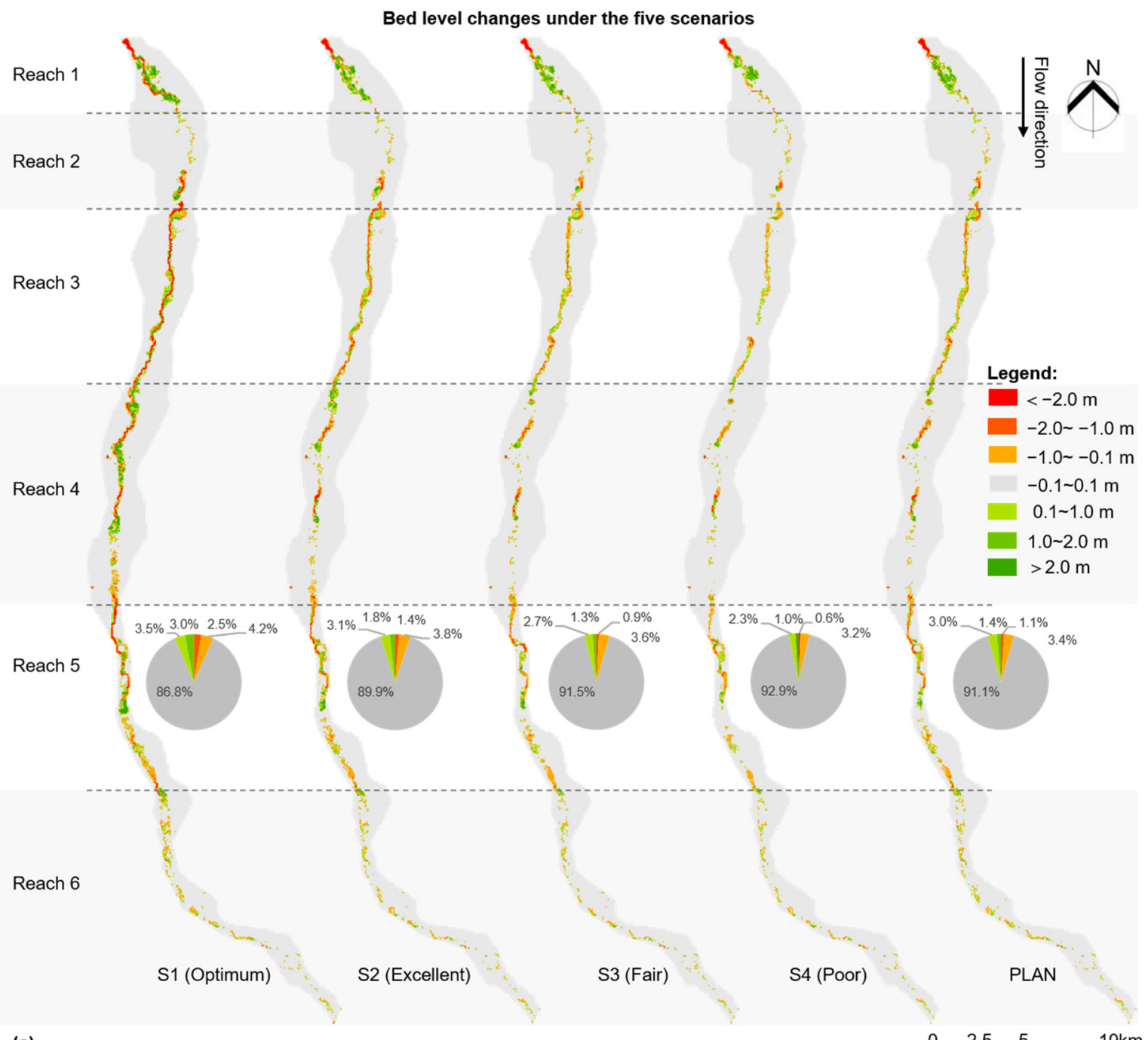

(a)

(b) Deposition and erosion areas, and total sediment volume of the five scenarios

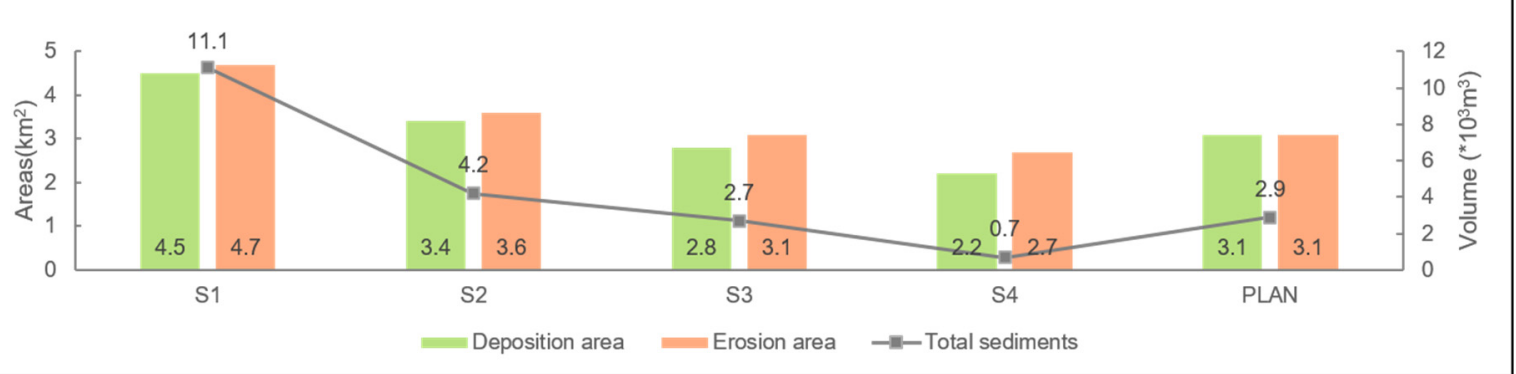

Figure 10. (a) Distribution of bed elevation changes under each scenario; (b) Deposition and erosion areas, and total sediment volume of the five scenarios.

\subsection{Habitat Suitability}

Using flow velocity and water depth outputs from C-L, we calculated CSI, WUA, HHS, and the WUA/flow volume ratio for each month of the 10th year for all scenarios. The 12-month averages of WUA and HHS (Figure 11, Table S7) decreased as the discharge decreased from S1 to S4. However, PLAN exceeded S4 and showed comparable WUA and HHS to S3, although its total flow replenishment volume was smaller than S3. The highest WUA occurred in July for S1-S4 and April and May for PLAN, whereas the timing of the lowest WUA was more variable, ranging from January, February, to May. Lastly, regarding 
the average ratio of WUA/flow volume, PLAN ranked the highest, whereas S1 ranked the lowest (Table S7).

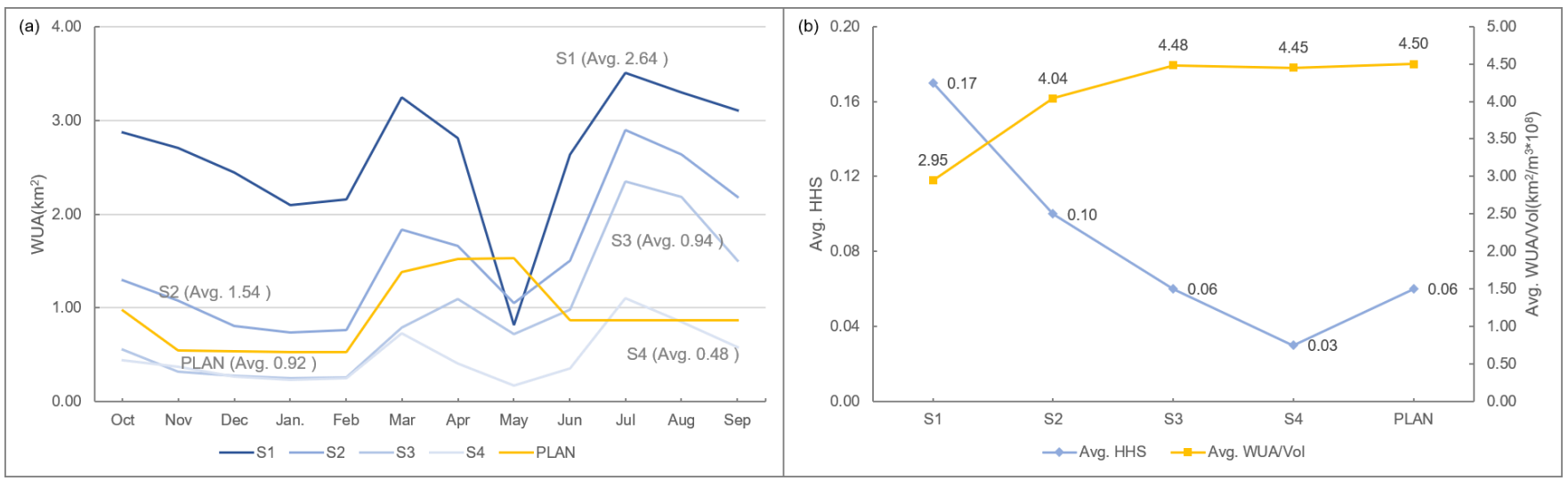

Figure 11. (a) Monthly average WUA of the five scenarios during the 10th year. (b) Average HHS and Average WUA/Vol. of the five scenarios.

Second, regarding the distribution of habitat areas, the 12-month average $\%$ of wetted areas with high and medium CSIs decreased as the discharge decreased from S1 to S4, varying from $19.0 \%$ (S1) to $1.8 \%$ (S4) (Figure 12a). Again, PLAN nearly equaled to S3. The largest habitat areas with high/medium CSIs occurred in July for S1-S4 and April for PLAN (Figure 12b-f). S1 and S2 showed more even distributions of high/medium CSI areas than S3 and S4, which showed long gaps (4-8 months) with minimal high-CSI areas in particular.

Third, to illustrate the habitat effects under high flows, we calculated and plotted the spatial distribution of CSI in Year 10 when the largest high/medium CSI areas occurred for each scenario, i.e., July for S1-S4 and on the last day of the $60 \mathrm{~m}^{3} / \mathrm{s}$ high-flow event for PLAN. The high- and medium-CSI areas ranged from $1.17 \mathrm{~km}^{2}$ (S4) to $4.60 \mathrm{~km}^{2}$ (S1). PLAN ranked second $\left(3.82 \mathrm{~km}^{2}\right.$ ) following S1 (Table S8). In all scenarios, Reaches 3 and 5 with a distinct channel structure showed consistently high CSI values (Figure 13). Other reaches showed variable CSI distributions under different scenarios. In particular, Reaches 1, 2, 4, and 6 showed minimum suitability under S4, and the sandpit in Reach 2 and agricultural fields at the southern end of Reach 6 showed consistently low suitability in all scenarios. 

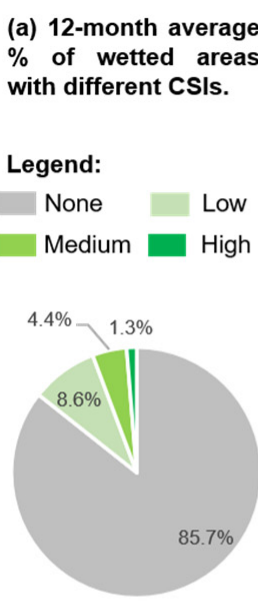

PLAN

(c) $\$ 1$ (Optimum)

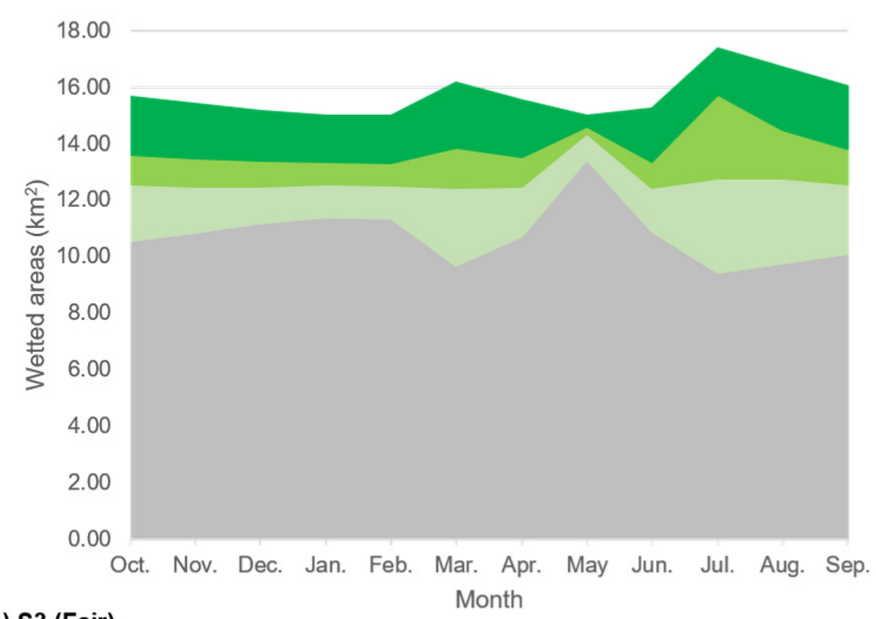

(e) S3 (Fair)

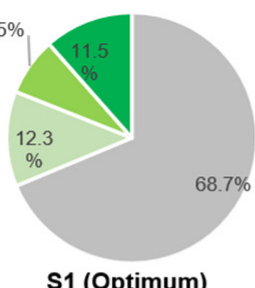

ptimum

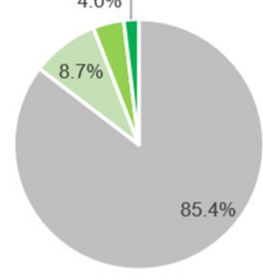

S3 (Fair)
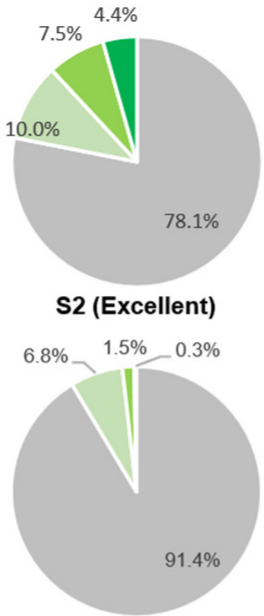

S4 (Poor)

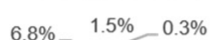

\section{(b) PLAN}
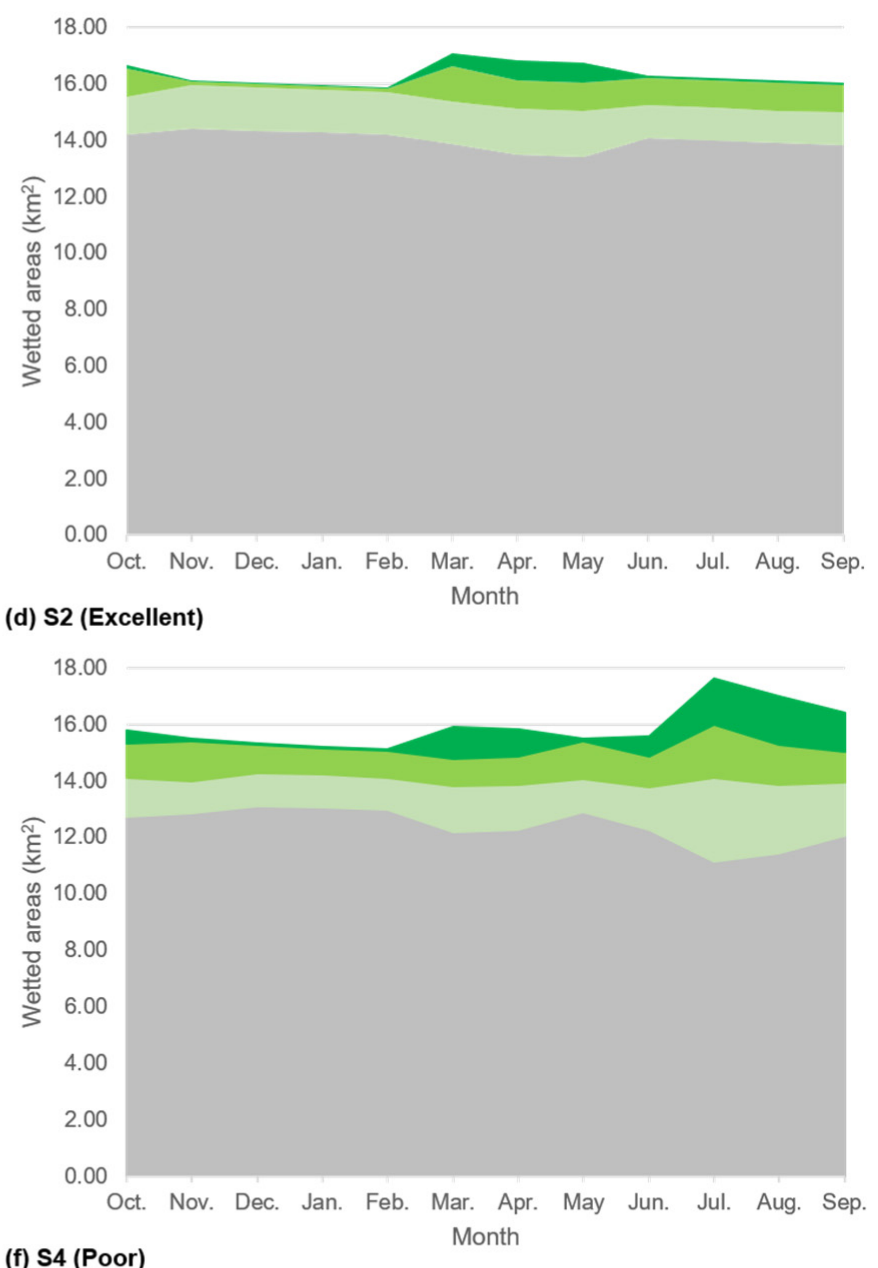

(f) $\mathrm{S} 4$ (Poor)

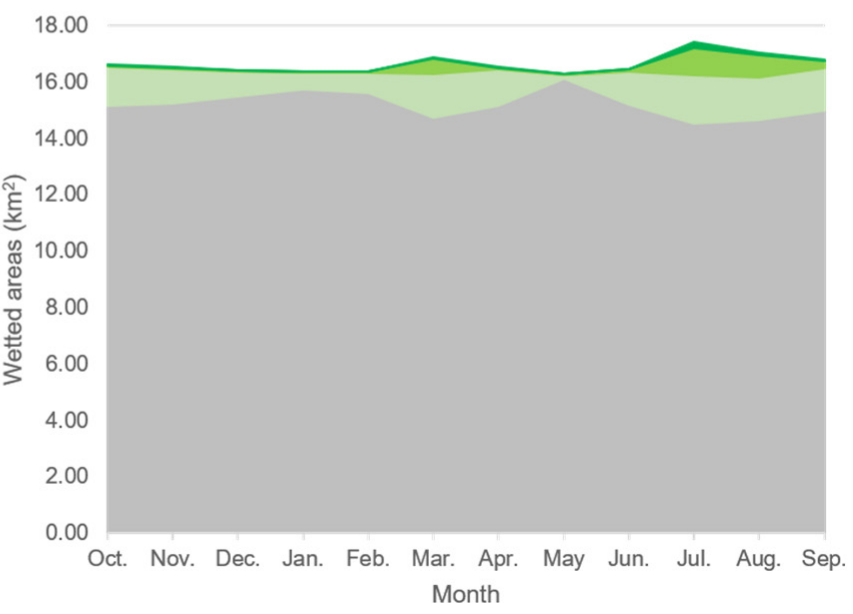

Figure 12. (a) The 12-month average percentage of wetted areas with different CSIs; (b-f) Distribution of habitat areas with high, medium, and low CSI values in Year 10 under each scenario. 


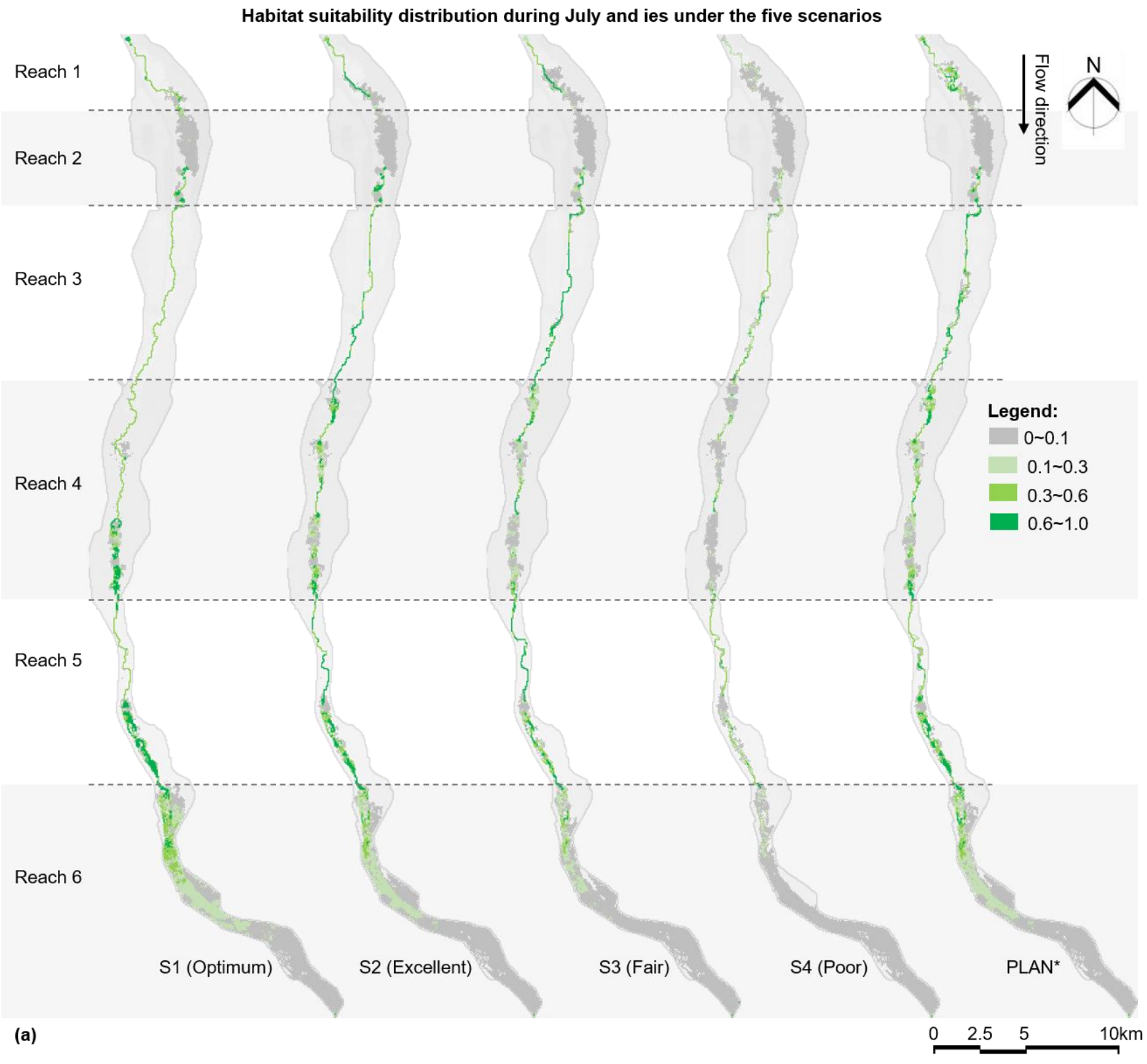

(b) Habitat areas with high, medium, and low CSI values in Year 10 when the largest high and medium CSI areas occurred.

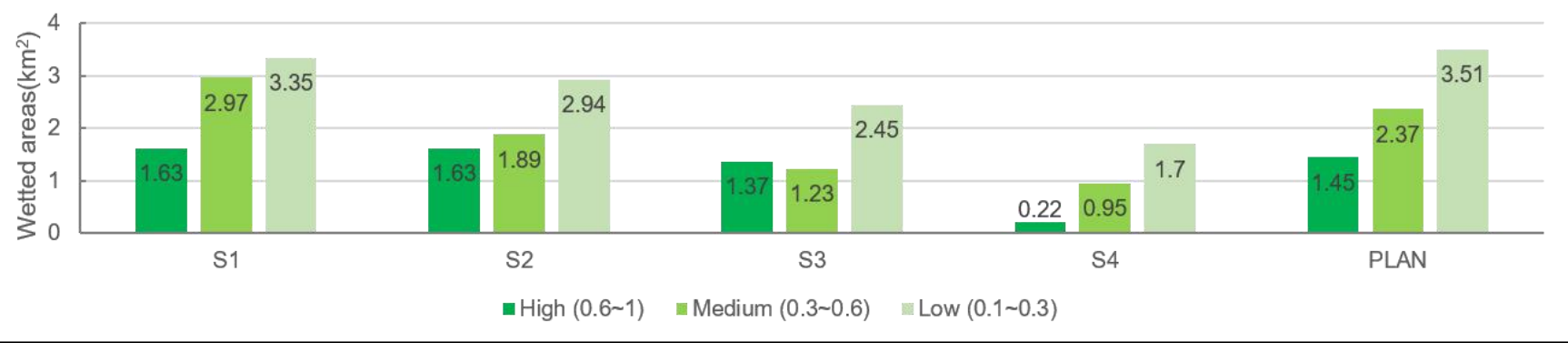

Figure 13. (a) CSI distribution when the largest high and medium CSI areas occurred in Year 10 under each scenario; (b) Habitat areas with high, medium, and low CSI values in Year 10 under each scenario when the largest high and medium CSI areas occurred. 


\section{Discussion}

\subsection{Geomorphology and Habitat Suitability Effects of Flow Scenarios}

As previously mentioned, a significant widening of most reaches (except Reach 3) was evident in all five future scenarios (average summer surface water width 304.7-339.8 m) in comparison to historical conditions in 1964/1980 (189.3-149.5 m). In particular, the widening of reaches 2 and 6 was primarily due to mining and agricultural activities since the 1980s, whereas the narrowing of Reach 3 can be attributed to flow restriction by riparian tree planting during 2005-2008.

The five flow scenarios showed overall small differences in monthly average wetted area, average surface water width in summer, water depth and flow velocity distributions, and bed level changes. All scenarios had comparable average wetted areas (i.e., 15.68-16.65 km², Table S2), summer average surface water width (304.7-339.8 m), water depth (averaged depth $\sim 2.5 \mathrm{~m}$ ), flow velocity distributions (e.g., $98.8-99.5 \%$ occurrences for velocity $<1 \mathrm{~m} / \mathrm{s}$ ), and bed elevation changes (86.8-92.9\% change within $-0.1-+0.1 \mathrm{~m}$ ).

However, when individual reaches were examined, cross-scenario variations were more pronounced. For example, the three reaches of 1,3 , and 4 were where morphological differences were the most prominent across the five future scenarios (Figures 8 and 10 depth/bed level changes). Within these reaches, a distinct channel formed under high-flow scenarios (S1) while shallow water remained the primary habitat type under other lowerflow scenarios. On the contrary, reaches 2 and 6 presented minor changes (Figure 10a), indicating the limited effectiveness of flows in reshaping these reaches.

With respect to habitat suitability for Carassius auratus, higher flows generally led to larger and more evenly distributed habitat areas with high/medium CSIs. However, higher flows in $\mathrm{S} 1$ appeared to have generated limited payback in habitat creation, as suggested by its lowest WUA/flow volume value. On the contrary, while PLAN had a small flow volume, its highest WUA/flow volume value and comparable WUA and HHS to S3 send an optimistic message that low monthly flows combined with high flow events can be a viable option when upstream water sources are limited. We will elaborate more on the effects of high flows in Section 4.3 below.

\subsection{Legacy Channel Alterations Affect Flow Replenishment Effectiveness}

The limited morphological effects above indicated that extensive, historic geomorphic modifications could have played a significant role in limiting the ability of the prescribed flow regimes to reshape the channel. Specifically, reaches 2 and 6, the two reaches that have endured sand mining and farming, showed no significant morphological changes under any scenario. In the former, a massive sandpit $(900 \mathrm{~m}$ in diameter, $23.6 \mathrm{~m}$ below its east bank at the lowest point) led to a large, deep pond in all scenarios. In contrast, in the latter, over 20 years of farming created large shallow open water areas in all scenarios. None of the scenarios had currents strong enough to form a distinct channel. Similarly, the habitat suitability indexes remained low for reaches 2 and 6 throughout the year, regardless of the flow scenario (Figure 13a). Therefore, for heavily modified rivers, flow replenishment alone is not enough to achieve the desired morphological and ecological effects, echoing literature findings that channel form and morphologic complexity can be as important as flow for providing habitat [65-68]. Managing for flows purely relative to a historic natural flow regime may be insufficient without the appropriate considerations for the hydraulic and morphological outcomes.

For reaches 2 and 6 at least, the channel structure needs to be restored to a certain degree for environmental flow implementation to effectively influence habitat. For example, restoring the channel structure in these reaches to mimic pre-1980s historical conditions could set the stage for re-establishing the dynamic process-response relationship between the flow regime and its geomorphic and ecological outcomes. However, the new channel design should be based on management objectives and the anticipated future flow and sediment regimes. Additionally, to enhance financial feasibility, bed and bank topography can be carefully modified to create a solution with an in-channel cut-and-fill balance to 
reduce the cost. For example, the farmland in Reach 6 can be excavated to form a distinct channel, and the cut materials can be utilized to partially fill the sandpit and create a channel connection in Reach 2. Future simulations can be conducted to assess specific channel design scenarios. Again, the revealing of limited ecological benefits due to legacy channel modifications highlights the significance of the landscape evolution modeling approach for evaluating proposed flow regimes and channel designs in heavily modified rivers.

Moreover, social and economic impacts should be assessed in searching for an ideal channel restoration plan. For example, restoring the channel structure in Reach 6's farmland will inevitably affect farmers' social and economic well-being. A thorough and thoughtful public participation process can help gain public recognition and support, while strategies such as land swap and monetary compensation could help mitigate adverse financial impacts to the farmers.

\subsection{High Flows Effectively Create Habitat}

Despite a smaller annual flow replenishment volume, the outperformance of the PLAN scenario over S2 and S3 in multiple geomorphic and habitat suitability metrics confirmed the positive effects of high flows. With $76 \%\left(260\right.$ of 340 million $\left.\mathrm{m}^{3}\right)$ of the flow volume of S3, PLAN transported a larger amount of sediments than S3 (2900 vs. $2700 \mathrm{~m}^{3}$ ). PLAN also equaled to S3 in the 12-month average HHS (0.06, Table S7, Figure 11b) and percentages of high/medium CSI areas (5.7\% vs. $5.9 \%$, Figure 12). Moreover, the $60 \mathrm{~m}^{3} / \mathrm{s}$ high-flow event in PLAN created a larger high/medium CSI area than S2 through S4 when their high flows occurred in July (e.g., $3.82 \mathrm{~km}^{2}$ in PLAN vs. $3.52 \mathrm{~km}^{2}$ in S2). On the other hand, although it is difficult to use a single metric to compare PLAN with S1, which requires 5.6 times of flow volume (1450 million $\left.\mathrm{m}^{3}\right)$ as PLAN, a qualitative assessment can be made that $\mathrm{S} 1$ may not offer proportional ecological benefits. For example, the 12-month average HHS was 2.8 times higher in S1 than PLAN ( 0.17 vs. 0.06); the 12-month average \% of high/medium CSI areas was 3.3 times higher in S1 than PLAN; the peak high/medium CSI area was only 1.2 times higher in S1 than PLAN. These comparisons highlight the effectiveness of high-flow events in PLAN in shaping the aquatic habitat.

Despite its evident habitat effects, the arbitrarily chosen $60 \mathrm{~m}^{3} / \mathrm{s}$ event in PLAN may not be high enough for the channel to regenerate habitat. It was only slightly higher than the high flow threshold $\left(49 \mathrm{~m}^{3} / \mathrm{s}\right)$ but significantly lower than the small flood threshold $\left(422.4 \mathrm{~m}^{3} / \mathrm{s}\right)$ revealed by the previous IHA analysis. Occasional artificial floods, such as two- to five-year return period events $\left(160-820 \mathrm{~m}^{3} / \mathrm{s}\right.$ in this case), can be crucial for maintaining sediment and floodplain dynamics [25]. Future modeling will be necessary to help identify alternative flow regimes that incorporate potentially higher flows (e.g., at a lower frequency) to more effectively create habitat. These alternative flow regimes should be developed within the context of the priority management objectives for the restoration effort.

\subsection{Thoughts on Future Directions}

Substantial investments are being made to improve the condition of and the diverse social benefits that can be provided by the YDR, specifically in the form of an annual replenishment water volume of 260 million $\mathrm{m}^{3}$ implemented through environmental flow releases. This study assessed the relative improvements that might be achieved through different water allocation scenarios, and more broadly highlights the value of using a landscape perspective and scenario-based approach to help guide future restoration efforts. Of critical importance is the need for any management action to be taken through an integrated water resource management (IWRM) framework, based on clearly articulated restoration objectives that couple efforts of managing flow and sediment regimes and channel structure in the basin.

Adding to the challenge is the uncertainty associated with climate change and resulting precipitation patterns, water availability, and possible flow regimes. As is, the current replenishment volume of 260 million $\mathrm{m}^{3}$ remains a fraction $(\sim 18 \%)$ of the historical 
average annual discharges (1.453 billion $\mathrm{m}^{3}$ ) during 1920-1950. Moreover, the current sole reliance on cross-basin transport of water for environmental flow purposes may be highly vulnerable under climatic uncertainty and face fierce competition from other water uses. However, a landscape perspective and strategies developed and advanced through IWRM afford opportunity. For example, water conservation efforts could be adopted in upstream sub-watersheds, especially for the agricultural sector which is the largest water use in the YDRB [69]. Moreover, substantial potential exists in the reclamation of local greywater and stormwater as additional sources for in-stream flows. For example, research has shown that 75 million $\mathrm{m}^{3}$ of greywater can be reused to supply the YDR every year [70], although the potential of stormwater management remains unassessed. Developing an integrated management plan that incorporates basin-wide stormwater management and the distribution and treatment of reclaimed water will be a critical next step to enhance the overall ecological conditions of the entire basin and the benefits it provides society.

Finally, as with other restoration efforts, work to enhance the YDR should include monitoring and be advanced through adaptive management to ensure that investments are returning benefits and improving scientific understanding that can be used to guide future management of this dynamic and heavily modified system. Long-term monitoring studies will require cooperation across many disciplines such as climate science, hydrology, geomorphology, ecology, engineering, and landscape planning and design; while adaptive management will require policymakers and managers to be an integral part of the team to ensure swift management actions can be made in response to monitoring outcomes.

\subsection{Study Limitations}

With important implications for urban river rehabilitation in water-scarce cities in China, we note several limitations of our study, some of which are not uncommon for similar studies. First, as with others with habitat suitability curves, the evaluation of the scenarios relied on a minimal number of HSCs. That was primarily due to the scarcity of ecological baseline data with extensive ecosystem disturbance since the 1980s. Although using a single set of HSCs to represent one species' requirements has been common, numerous authors have suggested adopting broadened criteria such as those representing habitat guilds [71-74] or multiple indicator species with drastically different seasonal needs [75]. Future efforts should be made to communicate with regional ecologists to create additional habitat suitability curves or information to test geomorphic and ecological consequences for other species to optimize flow allocations.

Additionally, the computational limitation of C-L does not allow a large number of scenarios to be tested within a short amount of time. Our pilot modeling began to reveal the potential consequences of chosen scenarios but showed a limited capacity to test interventions. As mentioned above, future modeling should continue to evaluate various channel modification scenarios of the mine pits and agricultural field at the minimum. Other flow replenishment scenarios that further incorporate the environmental flow components calculated by IHA should also be tested.

\section{Conclusions}

By connecting the landscape evolution model CAESAR-Lisflood with the habitat suitability index method, we assessed the morphological outcomes and habitat suitability under five environmental flow scenarios for the highly urbanized Yongding River of Beijing, China. We found that, first, although the five flow scenarios showed minor differences in metrics such as monthly average wetted area, average surface water width in summer, water depth and flow velocity distributions, and bed level changes, cross-scenario variations were more pronounced in specific reaches, where high- instead of low-flow scenarios were able to shape a distinct channel. The lack of physical responses of the other reaches may be attributed to historical channel modifications such as in-stream mining and agriculture. Second, the higher-flow scenarios generally led to larger and more evenly distributed habitat areas with high and medium suitability for Carassius auratus. 
However, the PLAN scenario with the second smallest total flow volume generated the highest payback in habitat creation, suggesting that low monthly flows combined with high-flow events show promise when upstream water sources are limited. Overall, for heavily modified urban rivers, flow replenishment based on historical monthly average flows alone may not be adequate to generate the desired morphological and ecological effects. Severe historical channel modifications have to be addressed for flow replenishment to take effect, and the potential for high flows of various magnitudes to shape the channel needs to be further explored to inform future environmental flow management.

This study is the first landscape evolution modeling study of a heavily modified urban stream in China to the best of the authors' knowledge. While this pilot study has various limitations due to severe data and knowledge shortages, it demonstrated the broad applicability of an interdisciplinary modeling framework based on LEMs and habitat suitability assessment. Moreover, it generated both transferable lessons and specific implications for future research and practices for the Yongding River. Enhancing heavily disturbed stream ecosystems in the face of wicked problems such as water scarcity will continue to challenge our planning and design capabilities. Simulations that test alternative restoration strategies should be leveraged in parallel to the field monitoring of ongoing restoration efforts to guide future restoration actions.

Supplementary Materials: The following are available online at https:/ / www.mdpi.com/article/10 .3390/w13223244/s1, Table S1: CAESAR-Lisflood parameter settings; Table S2: Monthly average wetted areas in the 10th year; Table S3: Surface water widths (June-August averages in Year 10) of the five scenarios compared to 1967 \& 1980; Table S4: Water depth distribution in the 10th year; Table S5: Flow velocity frequency distribution when the highest average velocity occurred (i.e., July for S1-S4 and March for PLAN); Table S6: Bed elevation changes, deposition and erosion areas, and total sediment volume; Table S7: WUA, HHS, and WUA/flow volume ratio of the five scenarios during the 10th year; Table S8: Habitat areas with high, medium, and low CSI values in Year 10 when the largest high and medium CSI areas occurred.

Author Contributions: Conceptualization, M.W. and H.W.; methodology, M.W., H.W. and A.T.W.; software, M.W.; validation, M.W., H.W. and H.L.; formal analysis, M.W. and H.W.; investigation, M.W. and H.L.; resources, M.W. and Z.L.; data curation, M.W.; writing—original draft preparation, M.W. and H.W.; writing—review and editing, H.W., and A.T.W.; visualization, M.W.; supervision, H.W.; project administration, H.W.; funding acquisition, Z.L. All authors have read and agreed to the published version of the manuscript.

Funding: Chinese National Science and Technology Major Project, grant number 2018ZX07101005.

Data Availability Statement: The data presented in this study are available on request from the corresponding author.

Acknowledgments: The authors wish to thank the China Institute of Water Resources and Hydropower Research and the Beijing Water Science \& Technology Institute for providing essential data to support the simulation. Additionally, gratitude is extended to the China Scholarship Council for granting a visiting scholarship to The Pennsylvania State University.

Conflicts of Interest: The authors declare no conflict of interest.

\section{References}

1. Dong, Z.R. Targets for Ecological Recovery of Rivers. China Water Resour. 2004, 10, 6-9+5. (In Chinese)

2. Zhang, Y.Z.; Zhou, Y.X.; Liu, H.L. Research on Evaluation of River Disturbance and Mapping of Spatial Distribution of Rivers at National Scale in China. Landsc. Archit. 2020, 27, 10-17. [CrossRef]

3. Ministry of Water Resources; National Bureau of Statistics. Bulletin of First National Census for Water; China Water \& Power Press: Beijing, China, 2013.

4. Speed, R.A.; Li, Y.; Tickner, D.; Huang, H.; Naiman, R.J.; Cao, J.; Lei, G.; Yu, L.; Sayers, P.; Zhao, Z.; et al. A framework for strategic river restoration in China. Water Int. 2016, 41, 998-1015. [CrossRef]

5. Jiang, Y. China's water scarcity. J. Environ. Manag. 2009, 90, 3185-3196. [CrossRef]

6. Dong, Z.R. Stages of River Protection Development and Considerations. China Water Resour. 2004, 17, 5, 16-17, 32.

7. Fu, F.; Dong, L. Review of Research on Landscape Planning Design of Rivers. Urban Stud. 2010, 17, 142-145. 
8. National Research Council. Restoration of Aquatic Ecosystems: Science, Technology, and Public Policy; National Academy Press: Washington, DC, USA, 1992.

9. Liu, H.L.; Zhou, Y.X.; Wu, S.Y.; Winn, T. Study on Natural and Scenic River Protection in Western China Based on the Com-parison Study between China and USA. Landsc. Archit. 2019, 35, 59-64.

10. Liu, J.Y.; Wu, D.Z. Comparative Study of Foreign River Ecological Restoration Implementation Mechanism and Its Enlightement to China. Landsc. Archit. 2016, 32, 121-127.

11. Meitzen, K.M.; Doyle, M.W.; Thoms, M.; Burns, C.E. Geomorphology within the interdisciplinary science of environmental flows. Geomorphology 2013, 200, 143-154. [CrossRef]

12. Lin, J.Q.; Chen, K.Q.; Cao, X.H.; Qi, C.H.; Fan, B.; Peng, Q.D. A thought on top-level design of river ecological restoration. J. Hydraul. Eng. 2018, 49, 483-491.

13. CPCCC; State Council. Decision from the CPC Central Committee and the State Council on Accelerating Water Conservancy Reform and Development; CCCPC and State Council: Beijing, China, 2010; pp. 1-8. Available online: http://www.gov.cn/jrzg/2011-01/29 / content_1795245.htm (accessed on 30 October 2021).

14. Committee of Almanac of China Water Resources Editors. Almanac of China Water Resources 2018; China Water \& Power Press: Beijing, China, 2018.

15. Brisbane Declaration. The Brisbane Declaration: Environmental Flows Are Essential for Freshwater Ecosystem Health and Human Well-Being. In Proceedings of the 10th International River Symposium, Brisbane, Australia, 3-6 September 2007; pp. 3-6.

16. Lian, Y.; Wang, X.G.; Huang, C.; Liu, G.H.; Wang, R.L.; Zhang, S.F.; Liu, Y.L.; Pedroli, B.; Van Eupen, M. Environmental Flows Evaluation Based on Eco-hydrology in the Yellow River Delta Wetlands. Acta Geogr. Sin. 2008, 63, 424-434.

17. Xu, W.; Yang, Z.; Chen, X.J.; Tao, X.J.; Li, J.Y. Three Gorges Reservoir Ecological Operation Effect on the Spawning of the Four Major Chinese Carps. Res. Environ. Sci. 2020, 33, 1129-1139.

18. Wan, C.; Zhou, T.; Zhang, J.W.; Wang, D.Z. Preliminary outcome of Integrated management of Yongding River Basin. China Water Resour. 2020, 17, 28-30.

19. Zhang, J.W.; Wan, C.; Du, Z.G.; Wang, D.Z. Study on the protection mechanism of ecological water usage of Yongding River. Beijing Water 2020, 5, 1-4.

20. Liu, J.; Yang, W.; Chu, J.-H.; Kuo, H.-H.; Analytis, J.G.; Fisher, I.R. Water Sustainability for China and Beyond. Science 2012, 337, 649-650. [CrossRef]

21. Poff, N.L.; Allan, J.D.; Bain, M.B.; Karr, J.R.; Prestegaard, K.L.; Richter, B.D.; Sparks, R.E.; Stromberg, J. The natural flow regime: A paradigm for river conservation and restoration. BioScience 1997, 11, 769-784. [CrossRef]

22. Jackson, C.R.; Pringle, C.M. Ecological Benefits of Reduced Hydrologic Connectivity in Intensively Developed Landscapes. BioScience 2010, 60, 37-46. [CrossRef]

23. Nilsson, C.; Jansson, R.; Malmqvist, B.; Naiman, R.J. Restoring Riverine Landscapes: The Challenge of Identifying Priorities, Reference States, and Techniques. Ecol. Soc. 2007, 12. [CrossRef]

24. Tharme, R.E. A global perspective on environmental flow assessment: Emerging trends in the development and application of environmental flow methodologies for rivers. River Res. Appl. 2003, 19, 397-441. [CrossRef]

25. Tegos, A.; Schlüter, W.; Gibbons, N.; Katselis, Y.; Efstratiadis, A. Assessment of Environmental Flows from Complexity to Parsimony-Lessons from Lesotho. Water 2018, 10, 1293. [CrossRef]

26. Kondolf, G.M. The Espace de Liberté and Restoration of Fluvial Process: When Can the River Restore Itself and When Must We Intervene? River Conservation and Management, 1st ed.; Wiley-Blackwell: Hoboken, NJ, USA, 2012; pp. 223-241.

27. Wohl, E.; Bledsoe, B.P.; Jacobson, R.B.; Poff, N.L.; Rathburn, S.L.; Walters, D.M.; Wilcox, A.C. The Natural Sediment Regime in Rivers: Broadening the Foundation for Ecosystem Management. BioScience 2015, 65, 358-371. [CrossRef]

28. Arkle, R.; Pilliod, D. Stream Restoration is Influenced by Details of Engineered Habitats at a Headwater Mine Site. Diversity 2021, 13, 48. [CrossRef]

29. Dunbar, M.J.; Alfredsen, K.; Harby, A. Hydraulic-habitat modelling for setting environmental river flow needs for salmonids. Fish. Manag. Ecol. 2011, 19, 500-517. [CrossRef]

30. Whipple, A.A.; Viers, J.H. Coupling landscapes and river flows to restore highly modified rivers. Water Resour. Res. 2019. [CrossRef]

31. Piégay, H.; Kondolf, G.M.; Sear, D.A. Integrating geomorphological tools to address practical problems in river management and restoration. Tools Fluv. Geomorphol. 2016, 507-532. [CrossRef]

32. Coulthard, T.J.; Neal, J.C.; Bates, P.D.; Ramirez, J.; de Almeida, G.A.M.; Hancock, G.R. Integrating the LISFLOOD-FP 2D hydrodynamic model with the CAESAR model: Implications for modelling landscape evolution. Earth Surf. Process. Landf. 2013, 38, 1897-1906. [CrossRef]

33. Coulthard, T.J. Landscape evolution models: A software review. Hydrol. Process. 2001, 15, 165-173. [CrossRef]

34. Tucker, G.E.; Hancock, G.R. Modelling landscape evolution. Earth Surf. Process. Landf. 2010, 35, 28-50. [CrossRef]

35. Conallin, J.; Boegh, E.; Jensen, J.K. Instream physical habitat modelling types: An analysis as stream hydromorphological modelling tools for EU water resource managers. Int. J. River Basin Manag. 2010, 8, 93-107. [CrossRef]

36. Bovee, K.D. Development and Evaluation of Habitat Suitability Criteria for Use in the Instream Flow Incremental Methodology; FWS/OBS86/7; USDI Fish and Wildlife Service: Washington, DC, USA, 1986; p. 235. 
37. Richter, B.D.; Baumgartner, J.V.; Powell, J.; Braun, D.P. A Method for Assessing Hydrologic Alteration within Ecosystems. Conserv. Biol. 1996, 10, 1163-1174. [CrossRef]

38. Men, B.H.; Liu, C.M.; Xia, J.; Liu, S.X.; Ji, L.N. Estimating and Evaluating on Minimum Ecological Flow of Western Route Project of China's South-to-North Water Transfer Scheme for Water Exporting Rivers. J. Soil Water Conserv. 2005, 19, 137-140.

39. U.S. Fish Wildlife Service. Standards for the Development of Habitat Suitability Index Models; Technical Report 103 ESM, USDI Fish and Wildlife Service; Division of Ecological Services: Washington, DC, USA, 1981.

40. Mathews, R.; Richter, B.D. Application of the Indicators of Hydrologic Alteration Software in Environmental Flow Setting1. JAWRA J. Am. Water Resour. Assoc. 2007, 43, 1400-1413. [CrossRef]

41. Tennant, D.L. Instream Flow Regimens for Fish, Wildlife, Recreation and Related Environmental Resources. Fisheries 1976, 1, 6-10. [CrossRef]

42. Boner, M.C.; Furland, L.P. Seasonal Treatment and Variable Effluent Quality Based on Assimilative Capacity. Water Pollut. Control Fed. 1982, 10, 1408-1416.

43. Gu, B.J.; Wang, F.S.; Song, L.; Lv, H.X.; Cao, C. Calculation and configuration of ecological water requirements for Yongding river Guanting Gorge. Beijing Water 2017, 2, 12-18.

44. Coulthard, T.J.; Macklin, M.G.; Kirkby, M.J. A cellular model of Holocene upland river basin and alluvial fan evolution. Earth Surf. Process. Landf. 2002, 27, 269-288. [CrossRef]

45. Van De Wiel, M.J.; Coulthard, T.J.; Macklin, M.G.; Lewin, J. Embedding reach-scale fluvial dynamics within the CAESAR cellular automaton landscape evolution model. Geomorphology 2007, 90, 283-301. [CrossRef]

46. Bates, P.D.; Horritt, M.S.; Fewtrell, T.J. A simple inertial formulation of the shallow water equations for efficient two-dimensional flood inundation modelling. J. Hydrol. 2010, 387, 33-45. [CrossRef]

47. Roloff, G.J.; Kernohan, B.J. Evaluating Reliability of Habitat Suitability Index Models. Wildlife Soc. Bull. (1973-2006) 1999, 27, 973-985.

48. Payne, T.R. The concept of weighted usable area as relative suitability index. In Proceedings of the IFIM Users Workshop, Fort Collins, CO, USA, 1-5 June 2003; pp. 1-5.

49. Jiang, B.; Wong, C.P.; Lu, F.; Ouyang, Z.; Wang, Y. Drivers of drying on the Yongding River in Beijing. J. Hydrol. 2014, 519, 69-79. [CrossRef]

50. Peng, J.B. Research on the Private-Use of Public Eco-Space: A Case Study of Golf Course Construction in Beijing. Ph.D. Thesis, Department of Urban Planning and Design, Tsinghua University, Beijing, China, 2008.

51. Zhang, M.Q. Beijing Yongding river "Five lakes line" comprehensive management ideas and experience. Water Resour. Plan. Des. 2016, 2, 7-8, 20.

52. Beijing Water Science and Technology Institute. Innovation, Support, and Leadership: The Beijing Water Science and Tech-nology Institute (BWSTI) helped out on the replenishment of Yongding River. Beijing Water 2020, 4, 6-7.

53. Yang, N. Research on long-term mechanism of ecological water replenishment in Yongding River. Water Resour. Dev. Res. 2020, 20, 13-16.

54. Barkwith, A.; Hurst, M.D.; Jackson, C.; Wang, L.; Ellis, M.A.; Coulthard, T.J. Simulating the influences of groundwater on regional geomorphology using a distributed, dynamic, landscape evolution modelling platform. Environ. Model. Softw. 2015, 74, 1-20. [CrossRef]

55. Coulthard, T.J.; Van De Wiel, M.J. Modelling long term basin scale sediment connectivity, driven by spatial land use changes. Geomorphology 2017, 277, 265-281. [CrossRef]

56. Aronoff, S. Classification accuracy: A user approach. Photogramm. Eng. Remote Sens. 1982, 48, 1299-1307.

57. Patel, N.; Kaushal, B. Improvement of user's accuracy through classification of principal component images and stacked temporal images. Geo-Spat. Inf. Sci. 2010, 13, 243-248. [CrossRef]

58. Ziliani, L.; Surian, N.; Coulthard, T.J.; Tarantola, S. Reduced-complexity modeling of braided rivers: Assessing model performance by sensitivity analysis, calibration, and validation. J. Geophys. Res. Earth Surf. 2013, 118, 2243-2262. [CrossRef]

59. Brown, M.; Lewis, H.; Gunn, S. Linear spectral mixture models and support vector machines for remote sensing. IEEE Trans. Geosci. Remote Sens. 2000, 38, 2346-2360. [CrossRef]

60. Ge, J.; Qi, J.; Lofgren, B.; Moore, N.; Torbick, N.; Olson, J.M. Impacts of land use/cover classification accuracy on regional climate simulations. J. Geophys. Res. Space Phys. 2007, 112. [CrossRef]

61. Brooks, R.P. Improving Habitat Suitability Index Models. Wildlife Soc. Bull. (1973-2006) 1997, 25, $163-167$.

62. Zingraff-Hamed, A.; Noack, M.; Greulich, S.; Schwarzwälder, K.; Wantzen, K.M.; Pauleit, S. Model-Based Evaluation of Urban River Restoration: Conflicts between Sensitive Fish Species and Recreational Users. Sustainability 2018, 10, 1747. [CrossRef]

63. Zhou, X.S.; Hu, Z.; Cui, W.Y.; Xu, N.; Wang, L.M. Investigation of Fish Resource in the Yongding River System. Pearl River 2020, 41, 63-69.

64. Li, Q.; Liu, R.; Li, B.D.; Jiang, G.Z.; Zhang, X.H. Effect of Spur Dikes for Waterway Regulation on Fish Habitat in the Small to Middle Scale Municipal Rivers. Sci. Technol. Eng. 2016, 16, 57-62.

65. Jacobson, R.B.; Galat, D.L. Flow and form in rehabilitation of large-river ecosystems: An example from the Lower Missouri River. Geomorphology 2006, 77, 249-269. [CrossRef]

66. Nilsson, C.; Reidy, C.A.; Dynesius, M.; Revenga, C. Fragmentation and Flow Regulation of the World's Large River Systems. Science 2005, 308, 405-408. [CrossRef] 
67. Tockner, K.; Pusch, M.; Gessner, J.; Wolter, C. Domesticated ecosystems and novel communities: Challenges for the management of large rivers. Ecohydrol. Hydrobiol. 2011, 11, 167-174. [CrossRef]

68. Yarnell, S.M.; Petts, G.E.; Schmidt, J.C.; Whipple, A.A.; Beller, E.E.; Dahm, C.N.; Goodwin, P.; Viers, J.H. Functional Flows in Modified Riverscapes: Hydrographs, Habitats and Opportunities. BioScience 2015, 65, 963-972. [CrossRef]

69. Ministry of Water Resources. The Implementation Plan of the Agricultural Water-Saving Project in the Yongding River Basin; Ministry of Water Resources: Beijing, China, 2019.

70. Ji, Y.K.; Wu, C.X.; Zhu, B.S. Ecological Restoration of Yongding River Basin in the New Phase. Water Resour. Dev. Res. 2018, 18, 31-34.

71. Hauer, C.; Unfer, G.; Tritthart, M.; Formann, E.; Habersack, H. Variability of mesohabitat characteristics in riffle-pool reaches: Testing an integrative evaluation concept (FGC) for MEM-application. River Res. Appl. 2011, 27, 403-430. [CrossRef]

72. Leonard, P.M.; Orth, D.J. Use of Habitat Guilds of Fishes to Determine Instream Flow Requirements. N. Am. J. Fish. Manag. 1988, 8, 399-409. [CrossRef]

73. Parasiewicz, P.; Prus, P.; Suska, K.; Marcinkowski, P. “E = mc ${ }^{2}$ ” of Environmental Flows: A Conceptual Framework for Establishing a Fish-Biological Foundation for a Regionally Applicable Environmental Low-Flow Formula. Water 2018, 10, 1501. [CrossRef]

74. Welcomme, R.L.; Winemiller, K.O.; Cowx, I.G. Fish environmental guilds as a tool for assessment of ecological condition of rivers. River Res. Appl. 2006, 22, 377-396. [CrossRef]

75. Warner, A.T.; Bach, L.B.; Hickey, J.T. Restoring environmental flows through adaptive reservoir management: Planning, science, and implementation through the Sustainable Rivers Project. Hydrol. Sci. J. 2014, 59, 770-785. [CrossRef] 